\title{
Disadvantage and discrimination in self-employment: caste gaps in earnings in Indian small businesses
}

\author{
Ashwini Deshpande $\cdot$ Smriti Sharma
}

Accepted: 22 October 2015/Published online: 8 December 2015

(C) Springer Science+Business Media New York 2015

\begin{abstract}
Using the 2004-2005 India Human Development Survey data, we estimate and decompose the earnings of household businesses owned by historically marginalized social groups known as Scheduled Castes and Tribes (SCSTs) and non-SCSTs across the earnings distribution. We find clear differences in characteristics between the two types of businesses with the former faring significantly worse. The mean decomposition reveals that as much as $55 \%$ of the caste earnings gap could be attributed to the unexplained component. Quantile regressions suggest that gaps are higher at lower deciles, providing some evidence of a sticky floor. Finally, quantile decompositions reveal that the unexplained component is greater at the lower and middle deciles than higher, suggesting that SCST-owned businesses at the lower and middle end of the conditional earnings distribution face greater discrimination.
\end{abstract}

Keywords Caste $\cdot$ Discrimination $\cdot$ Household business · Earning gaps · Quantile decomposition · India

\footnotetext{
A. Deshpande $(\bowtie)$

Department of Economics, Delhi School of Economics, University of Delhi, Delhi 110007, India

e-mail: ashwini@econdse.org

S. Sharma

UNU-WIDER, Katajanokanlaituri 6B, 00160 Helsinki,

Finland

e-mail: smriti@wider.unu.edu
}

JEL Classifications $\mathrm{J} 31 \cdot \mathrm{J} 71 \cdot \mathrm{C} 21 \cdot \mathrm{O} 15 \cdot$ $\mathrm{O} 17 \cdot \mathrm{L} 26$

\section{Introduction}

Ethnic and racial discrimination in labor markets, as manifested in wage and occupational attainment gaps, has been widely examined (e.g., Altonji and Blank 1999; Antecol and Bedard 2004; Atal et al. 2009). In India too, labor market discrimination against historically disadvantaged caste groups, i.e., the former untouchables (Scheduled Castes or SCs) and marginalized tribal groups (Scheduled Tribes or STs), is well documented, with SCs and STs earning significantly lower wages and being allocated to less prestigious jobs as compared to upper castes, after controlling for their productive characteristics (Banerjee and Knight 1985; Madheswaran and Attewell 2007; Das and Dutta 2007). ${ }^{1}$ However, the disadvantage faced by these groups may not be limited merely to wage employment and could extend to the realm of self-employment as well. While there is a sizable literature from the USA that studies racial differences in entrepreneurship in terms of business creation rates, survival, employment, profits and net worth (e.g., Fairlie 2004, 2006; Ahn 2011; Lofstrom and Bates

\footnotetext{
${ }^{1}$ For detailed discussions on caste-based economic discrimination in India, see Deshpande (2011).
} 
2013), examination of such issues in the Indian context is relatively recent, due to data constraints. ${ }^{2}$

Our paper attempts to fill this gap for India, by assessing caste discrimination in household non-farm businesses ('businesses' hereafter), which has been possible due to the recent availability of good-quality earnings data for such businesses. Given the small scale of operations of these businesses, catering mostly to customers in the local community, it is highly plausible that businesses owned by low-caste owners face discrimination at the hands of customers, suppliers and lenders, since their caste status is easily identifiable, unlike in large businesses with complex ownership and management structures, where observing the caste of the owners might be less straightforward. However, discrimination could be directed toward larger low-caste businesses too: In personal interviews, rich SC entrepreneurs have discussed their individual battles with caste discrimination as they started their businesses. ${ }^{3}$ There are other ethnographic accounts as well (Jodhka 2010; Prakash 2010) that indicate the presence of persistent disadvantage and discrimination in the self-employment arena, which forms the motivation for the present study.

To the best of our knowledge, ours is the first paper to examine caste gaps in earnings from household businesses for India. We use the India Human Development Survey data for 2004-2005 and employ two methodologies for understanding the earnings structure of businesses: OLS estimation of mean earnings for businesses owned by SCs and STs and non-SCST businesses; and quantile regressions for a distributional analysis to look beyond the mean and to understand 'what happens where' in the earnings distribution. Correspondingly, we use decomposition strategies to decompose the earnings gap between SCST and non-SCST businesses into explained and unexplained components (with the latter being indicative of discrimination), at the mean and at various quantiles of the earnings distribution. ${ }^{4}$

\footnotetext{
2 The Employment-Unemployment Survey conducted by the National Sample Survey (NSS) collects data on earnings of salaried employees and casual workers, but not of the selfemployed.

${ }^{3}$ See, for instance, interviews in Outlook Business, May 2, 2009, p. 25.

${ }^{4}$ Large Indian data sets such as the NSS and Economic Census define four broad social groups: Scheduled Castes (SCs), Scheduled Tribes (STs), Other Backward Classes (OBCs) and
}

Our main findings are as follows. There are clear differences in observable characteristics between SCST and non-SCST businesses. The latter are more urban, record larger number of total man-hours, have better educated and richer owners, and are more likely to have a business in a fixed workplace. These disparities get reflected in both indicators of business performance in the data-gross receipts and net income-such that SCSTs, on average, perform significantly poorly compared to non-SCSTs. The Blinder-Oaxaca decomposition reveals that depending on the specification of variables, assuming that the non-discriminatory earning structure is that of nonSCSTs, at least $20 \%$ of the net income gap could be attributed to the unexplained or the discriminatory component. Unconditional caste gaps in earnings are higher at lower percentiles than at the higher percentiles. Thus, we find some evidence supporting a 'sticky floor,' a phenomenon observed in the context of gender wage gaps in developing countries (e.g., Chi and Li 2008; Carrillo et al. 2014). Quantile decompositions based on our preferred specification reveal that the unexplained component is significant in the middle part of the distribution (viz., between the fourth and eighth deciles), where it hovers around $15 \%$ of the total gap in earnings.

In addition to contributing to the broader literature on racial and ethnic disparities in small business ownership from a developing country perspective, this paper has significant policy implications, particularly in the context of the current discourse on 'Dalit Capitalism' in India-inspired by 'Black Capitalism' in the USA-by the Dalit Indian Chamber of Commerce and Industry (DICCI). ${ }^{5}$ DICCI believes that Dalits should enter business and industry sectors as entrepreneurs and use this route to become 'job givers, and not job seekers' especially for others in their own community and enhance their wealth, instead of being dependent on the state for benefits. However, the majority of Dalit businesses are small, owner-operated, survivalist household enterprises that do not have

\footnotetext{
Footnote 4 continued

'others.' 'Others' is a reasonable approximation of the upper castes. Even though these large omnibus administrative categories mask intra-group heterogeneity, it is standard practice to use these for empirical estimation since data are available only for these categories.

5 SCs use the term Dalit (meaning oppressed) as a term of pride. More details about DICCI can be found at www.dicci.org.
} 
the potential to generate either employment or wealth (Deshpande and Sharma 2013). Further, our results indicate that discriminatory tendencies that exist in labor markets may characterize business operations as well.

The rest of this paper is organized as follows: Sect. 2 contains a literature review; Sect. 3 outlines the methodology; Sect. 4 discusses the data and descriptive statistics; Sect. 5 presents the results, while Sect. 6 discusses our findings. Section 7 concludes.

\section{Review of related literature}

Iyer et al. (2013) and Thorat and Sadana (2009) in descriptive analyses using Indian Economic Census data document caste differences in non-agricultural enterprise ownership and performance. ${ }^{6}$ They find SCs and STs to be underrepresented relative to their population shares. Enterprises owned by SCSTs are smaller in terms of number of workers, hire mostly family labor, rely less on external sources of finance and operate mostly in the unregistered unorganized sector as compared to enterprises owned by nonSCSTs. Deshpande and Sharma (2013) examine unitlevel data from two successive censuses of the micro-, small and medium enterprises (MSME) sector to study the nature of participation of marginalized groups in self-employment and found that the MSME sector exhibits very clear differences along business owners' caste and gender, in virtually all business characteristics.

This evidence of systematic differences, however, does not prove discrimination; all the gaps in performance could, in principle, be accounted for by differences in characteristics of SCST and non-SCST businesses. ${ }^{7}$ For example, in the USA, racial disparities in asset ownership and family background in selfemployment (with blacks being more disadvantaged than whites) are among the most important factors leading to differences in business creation and

\footnotetext{
$\overline{6}$ Audretsch et al. (2013) use NSS data to explore the influence of religious and caste affiliation on occupation choice. They find SCs and STs to be less likely to be self-employed.

7 The fact that SCSTs possess inferior characteristics suggests some 'pre-market' discrimination (Deshpande 2011; Thorat and Newman 2010).
}

performance (Dunn and Holtz-Eakin 2000; Hout and Rosen 2000). However, even after controlling for differences in characteristics, a significant proportion of the performance gap remains unexplained and that could be on account of discrimination or some unobserved differences in behavior such as ability and risk aversion or some factors not amenable to measurement.

Discrimination manifests itself in self-employment primarily in the form of consumer and credit market discrimination. For example, Borjas and Bronars (1989) study consumer discrimination and find that relative gains of entering self-employment are reduced for ethnic minorities because they have to compensate white consumers by lowering prices charged for goods and services. Coate and Tennyson (1992) study credit discrimination assuming that lenders are unable to observe entrepreneurial ability. Individuals from a group discriminated against in the labor market will receive less favorable terms in the credit market since lenders know that for such individuals, the opportunity cost of entering self-employment is lower, and, thus, they are willing to take more risks. Such groups will be charged higher interest rates, thereby reducing the expected returns from self-employment. Empirical analyses using data from the USA show that the probability of loan denials and rates of interest charged on approved loans is higher for black-owned businesses than whites (Blanchflower et al. 2003) and probability of loan renewals is lesser for black- and Hispanic-owned businesses (Asiedu et al. 2012). Section 6 discusses the evidence from Prakash (2010), Jodhka (2010) and Kumar (2013), among others, to understand possible channels of discrimination against Dalit businesses in India.

\section{Methodology}

\subsection{Blinder-Oaxaca decomposition framework}

We first use the Blinder-Oaxaca method to decompose the mean earnings gap from self-employment between SCSTs and non-SCSTs into portions attributable to differences in characteristics (the explained component or composition effect) and differences in returns to these endowments (the unexplained component or coefficients effect) (Blinder 1973; Oaxaca 1973). While the unexplained 
component can be attributed to discrimination, it is highly plausible that this residual also includes the effects of either unmeasurable or unobservable characteristics. All decomposition exercises are subject to this caveat. However, it is equally true that some premarket discrimination affects the formation of characteristics, and thus, the explained component also embodies the effects of past discrimination. Therefore, estimates of the unexplained component from decomposition exercises should not be taken as precise measurements of 'true' discrimination, but as rough estimates, providing orders of magnitude.

This method involves estimating earnings equations separately for individuals $i$ of the different groups $g$, SCSTs (group $s$ ) and non-SCSTs (group $n$ ):

$w_{i g}=X_{i}^{g} \beta^{g}+u_{i}^{g}$

where $g=(n, s)$ denotes the two groups. The dependent variable $w$ is the natural log of earnings. $X_{i}$ is the vector of covariates for individual $i$, which contains characteristics that would determine earnings. $\beta$ is the corresponding vector of coefficients, and $u$ is the random error term.

The gross difference in earnings between the two groups can be written as:

$G=\bar{X}^{n} \hat{\beta}^{n}-\bar{X}^{s} \hat{\beta}^{s}$

In order to decompose this gap, some assumptions have to be made about the earnings structure that would prevail in the absence of discrimination and construct counterfactual earnings functions. One counterfactual could be constructed by assuming that the non-discriminatory earnings structure is the one applicable to non-SCSTs. ${ }^{8}$ In that case, the counterfactual earnings equation of the SCSTs would be written as:

$w_{i s}^{c}=X_{i}^{s} \beta^{n}+v_{i}^{s}$

Adding and subtracting the counterfactual earnings to Eq. (2), we arrive at:

$G=\bar{w}^{n}-\bar{w}^{s}=\left(\bar{X}^{n}-\bar{X}^{s}\right) \hat{\beta}^{n}+\bar{X}^{s}\left(\hat{\beta}^{n}-\hat{\beta}^{s}\right)$

\footnotetext{
${ }^{8}$ One could also construct an alternative counterfactual by assuming that the non-discriminatory earnings structure is the one applicable to the SCSTs. However, the counterfactual based on the non-SCST earnings structure is more intuitively appealing, as non-SCSTs are not discriminated against on account of their caste identity.
}

where the first term on the right-hand side represents the part of the earnings differential due to differences in characteristics and the second term represents differences due to varying returns to the same characteristics. The second term is the unexplained component and is considered to be a reflection of discrimination.

The decomposition is sensitive to the choice of the non-discriminatory earnings structure, as the two counterfactuals yield different estimates. To get around this 'index number problem,' one solution is to use the pooled estimates as the single counterfactual (Oaxaca and Ransom 1994). Another solution, suggested by Cotton (1988), is to construct the nondiscriminatory earnings structure as a convex linear combination of the earnings structures of both groups.

\subsection{Quantile regression decomposition framework}

Generalizing the traditional Blinder-Oaxaca decomposition to analyze earnings gaps at different parts of the earnings distribution, Machado and Mata (2005) proposed a decomposition method that involves estimating quantile regressions separately for the two subgroups and then constructing a counterfactual using covariates of one group and returns to those covariates for the other group.

The conditional earnings distribution is estimated by quantile regressions. The conditional quantile function $Q_{\theta}(w \mid X)$ can be expressed using a linear specification for each group as follows:

$Q_{\theta}\left(w_{g} \mid X_{g}\right)=X_{i, g}^{T} \beta_{g, \theta}$ for each $\theta \in(0,1)$

where $g=(n, s)$ denotes the two groups. $w$ is the natural $\log$ of earnings. $X_{i}$ is the set of covariates for individual $i, \beta_{\theta}$ are the coefficient vectors that need to be estimated for the different $\theta^{\text {th }}$ quantiles. The quantile regression coefficients can be interpreted as the returns to various characteristics at different quantiles of the conditional earnings distribution.

Next, Machado and Mata (2005) construct the counterfactual unconditional earnings distribution using estimates for the conditional quantile regressions, which consists of the following steps:

1. Generate a random sample of size $m$ from a uniform distribution $U[0,1]$ 
2. For each group, separately estimate $m$ different quantile regression coefficients

3. Generate a random sample of size $m$ with replacement from the empirical distribution of the covariates for each group, $X_{s, i}$ and $X_{n, i}$

4. Generate the counterfactual of interest by multiplying different combinations of quantile coefficients and distribution of observables between group $s$ and group $n$ after repeating this last step $m$ times.

Standard errors are computed using a bootstrapping technique.

This simulation-based estimator relies on the generation of a random sample with replacement to construct the counterfactual unconditional earnings distribution and comes at the cost of increased computational time. Melly (2006) proposed a procedure that is less computationally intensive and faster by integrating the conditional earnings distribution over the entire range of covariates to generate the marginal unconditional distribution of log earnings. This procedure uses all the information contained in the covariates and makes the estimator more efficient than the one suggested by Machado and Mata (2005). The Melly (2006) and Machado and Mata (2005) decompositions are numerically identical when the number of simulations in the latter goes to infinity.

We construct a counterfactual for the SCST group using the characteristics of SCSTs and the earning structure for non-SCSTs here:

$C F_{\theta}^{s}=X_{s, i}^{T} \beta_{n, \theta}$

This yields the following decomposition:

$$
\Delta_{\theta}=\left(Q_{n, \theta}-\mathrm{CF}_{\theta}^{s}\right)+\left(\mathrm{CF}_{\theta}^{s}-Q_{s, \theta}\right)
$$

The first term on the right-hand side represents the effect of characteristics (explained component) and the second the effect of returns to characteristics (coefficients effect or unexplained component).

\section{Data and descriptive statistics}

\subsection{Data}

We use the India Human Development Survey (IHDS) for 2004-2005, which is a nationally representative data set covering 41,554 households across 1504 villages and 971 urban states in 33 states of India. The modules of the survey collect data on a wide range of questions relating to economic activity, income and consumption expenditure, asset ownership, social capital, education, health, marriage and fertility, etc.

The survey module on household non-farm businesses does not identify the primary decision-maker in the business. However, we can identify specific members in the household who worked in the business and the amount of time they spent, in terms of days per year and hours per day. Using that information, we assume that the person who has spent maximum number of hours in the business is the de facto decision-maker.

We restrict the sample to those states where there are at least 50 household businesses, leaving us with 22 states. ${ }^{9}$ We consider only male businesses (i.e., where men are the primary decision-makers) in the main analysis because factors affecting selection into self-employment vary along lines of gender; additionally, in order to delineate the effect of caste, we need to hold gender constant, so as not to confound the effect of overlapping identities. ${ }^{10}$

The data canvasses information on two measures of financial performance of the business: net income and gross receipts. Our primary dependent variable is the $\log$ of net income from the business over the last 12 months. Net income is computed as gross receipts less hired workers' wages less cost of materials, rent, interest on loans, etc. One issue on which the data are patchy is the use of unpaid family labor in these businesses, which would affect the calculation of net income. While some businesses in the data report the individual components as well as a net income, others report only the net income. However, our queries with the IHDS team revealed that when hired labor is not reported, it cannot be assumed that no labor was

\footnotetext{
$\overline{9}$ These states are: Jammu and Kashmir, Himachal Pradesh, Punjab, Uttaranchal, Haryana, Delhi, Rajasthan, Uttar Pradesh, Bihar, Tripura, Assam, West Bengal, Jharkhand, Orissa, Chhattisgarh, Madhya Pradesh, Gujarat, Maharashtra, Andhra Pradesh, Karnataka, Kerala and Tamil Nadu.

${ }^{10}$ In Appendix 2, we report results of the mean decomposition for the sample of 1099 businesses where the primary decisionmakers are female (SCSTs: 266, non-SCSTs: 833). Since the total sample of 1099 females is not sufficient to estimate quantile decompositions with precision, we do not estimate those. Using the non-SCST coefficients, $68.7 \%$ of the mean earnings gap is explained using our preferred specification, with $31 \%$ remaining unexplained.
} 
actually hired. Thus, data do not allow us to clearly distinguish between hired and unpaid family labor, resulting in the inability to estimate 'true' net income. We, thus, use the net income figures in the data as reported. While expenditure-based indicators have been found to be more reliable than income-based measures in developing countries-on account of recall errors, non-response and deliberate mis-reporting-for an analysis focusing on enterprise performance, income is the most appropriate outcome to consider.

As explanatory variables, we use individual-specific variables such as age, marital status and standard years of education completed of the decision-maker; household-specific variables such as wealth (proxied by asset ownership), rural/urban status, whether someone close to or within the household is an official of the village panchayat/nagarpalika/ward committee and membership in the following: business or professional group; credit or savings group; caste association; development group and agricultural, milk or other co-operative; and business-specific variables such as number of family members who worked in the business, total number of hours put into the business, work place type and industry type. ${ }^{11}$ Admittedly, business-specific variables and some household-specific variables such as membership in different types of networks and wealth are potentially endogenous with respect to business performance. However, as Fortin et al. (2011) argue, decompositions are accounting exercises that allow one to quantify the contribution of factors to the difference in outcome between two groups without necessarily shedding any light on the mechanisms explaining the relationship between such factors and outcomes.

As our sample is limited to only those households that operate businesses, a potential limitation of our estimations is that coefficients of earnings regressions may be biased since individuals and households do not randomly select into self-employment. Unfortunately, our data set does not provide us with suitable instruments to correct for selection.

\subsection{Descriptive statistics}

Table 1 lists the summary statistics for the whole sample and for the sample of SCST and non-SCST

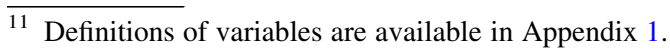

businesses separately. Of the total 7288 businesses, 1300 are owned by SCSTs (17.8\%) and the remaining 5988 by non-SCSTs $(82.2 \%){ }^{12}$

In terms of performance, the average net income for non-SCST businesses (Rs. 45,218) is 1.76 times that for SCST businesses (Rs. 25,640). A similar pattern can be seen in the average gross receipts. Figure 1 plots the kernel density distribution of log income for SCST and non-SCST businesses. The distribution of incomes of non-SCST businesses lies distinctly to the right of the SCST businesses.

This large difference in business performance could be on account of a variety of characteristics, in most of which there are clear differences between SCSTs and non-SCSTs. The primary decision-maker is on average 39 years old, and $86 \%$ of them are married. These numbers are similar across SCST and non-SCST decision-makers. However, average years of education differ significantly by caste, with 8.3 years for non-SCSTs and 5.7 years for SCSTs.

There is a distinctly different pattern in the ruralurban distribution across castes with $33 \%$ of SCST households and $53 \%$ of non-SCST households being located in urban areas. There is also disparity in material standard of living as reflected in asset ownership, in that out of the 16 assets in the questionnaire, non-SCSTs own approximately 8, while SCSTs own around $5 .{ }^{13} \mathrm{We}$ create a wealth index using principal components analysis and divide the sample into three groups following Filmer and Pritchett (2001): those lying in the bottom $40 \%$ (poor), middle $40 \%$ (middle) and the top $20 \%$ (rich). By this somewhat arbitrary definition, $65.2 \%$ of SCST households fall in the poor category, while $34.6 \%$ of non-SCST households are poor. 27.4 and $42.7 \%$ of SCSTs and non-SCSTs, respectively, are in the middle, and $7.4 \%$ of SCSTs and $22.7 \%$ of nonSCSTs are rich.

\footnotetext{
12 Since the decomposition methodology is applicable only to pairs of groups, we club together relatively similar groups, albeit with intra-group heterogeneity, into two broad dissimilar groups.

13 The IHDS data contain information on the ownership of the following 16 items (binary variables): cycle/bicycle, sewing machine, generator set, mixer/grinder, air cooler, motorcycle/ scooter, black and white television, color television, clock/ watch, electric fan, chair or table, cot, telephone, cell phone, refrigerator and pressure cooker.
} 
Table 1 Summary statistics
Standard errors are reported in parentheses. Net income is defined as gross receipts less hired workers' wages less all other expenses such as costs of materials, rent, interest on loans, etc

\begin{tabular}{|c|c|c|c|}
\hline Variable & $\begin{array}{l}\text { All } \\
\text { enterprises }\end{array}$ & $\begin{array}{l}\text { SCST } \\
\text { enterprises }\end{array}$ & $\begin{array}{l}\text { Non-SCST } \\
\text { enterprises }\end{array}$ \\
\hline \multicolumn{4}{|l|}{ Outcome variables } \\
\hline Gross receipts (Rs.) & $\begin{array}{l}108,015.8 \\
(258,019)\end{array}$ & $\begin{array}{c}58,804.02 \\
(98,524.46)\end{array}$ & $\begin{array}{c}118,708.7 \\
(279,809.3)\end{array}$ \\
\hline Net income (Rs.) & $\begin{array}{c}41,726.15 \\
(45,158.62)\end{array}$ & $\begin{array}{c}25,640.14 \\
(32,726.04)\end{array}$ & $\begin{array}{c}45,218.44 \\
(46,704.93)\end{array}$ \\
\hline \multicolumn{4}{|l|}{ Explanatory variables } \\
\hline \multicolumn{4}{|l|}{ Individual characteristics } \\
\hline Age (in years) & $\begin{array}{c}39.13 \\
(12.43)\end{array}$ & $\begin{array}{c}38.6 \\
(12.53)\end{array}$ & $\begin{array}{c}39.25 \\
(12.4)\end{array}$ \\
\hline Married & $\begin{array}{c}0.86 \\
(0.34)\end{array}$ & $\begin{array}{c}0.86 \\
(0.34)\end{array}$ & $\begin{array}{c}0.86 \\
(0.34)\end{array}$ \\
\hline Years of education & $\begin{array}{c}7.79 \\
(4.64)\end{array}$ & $\begin{array}{c}5.66 \\
(4.57)\end{array}$ & $\begin{array}{c}8.25 \\
(4.53)\end{array}$ \\
\hline \multicolumn{4}{|l|}{ Household characteristics } \\
\hline SCST & $\begin{array}{r}17.84 \\
(0.38)\end{array}$ & & \\
\hline Urban location & $\begin{array}{r}0.49 \\
(0.5)\end{array}$ & $\begin{array}{c}0.33 \\
(0.47)\end{array}$ & $\begin{array}{c}0.53 \\
(0.5)\end{array}$ \\
\hline \multicolumn{4}{|l|}{ Membership in } \\
\hline Business group & $\begin{array}{c}0.08 \\
(0.28)\end{array}$ & $\begin{array}{c}0.06 \\
(0.23)\end{array}$ & $\begin{array}{c}0.09 \\
(0.29)\end{array}$ \\
\hline Credit or savings group & $\begin{array}{c}0.07 \\
(0.26)\end{array}$ & $\begin{array}{c}0.07 \\
(0.26)\end{array}$ & $\begin{array}{c}0.07 \\
(0.26)\end{array}$ \\
\hline Caste association & $\begin{array}{c}0.14 \\
(0.35)\end{array}$ & $\begin{array}{c}0.13 \\
(0.33)\end{array}$ & $\begin{array}{c}0.15 \\
(0.35)\end{array}$ \\
\hline Development group & $\begin{array}{c}0.02 \\
(0.14)\end{array}$ & $\begin{array}{l}0.01 \\
(0.1)\end{array}$ & $\begin{array}{c}0.02 \\
(0.15)\end{array}$ \\
\hline Co-operative & $\begin{array}{c}0.03 \\
(0.18)\end{array}$ & $\begin{array}{c}0.02 \\
(0.15)\end{array}$ & $\begin{array}{c}0.04 \\
(0.19)\end{array}$ \\
\hline Village panchayat or ward committee & $\begin{array}{c}0.11 \\
(0.31)\end{array}$ & $\begin{array}{c}0.13 \\
(0.33)\end{array}$ & $\begin{array}{c}0.11 \\
(0.31)\end{array}$ \\
\hline \multicolumn{4}{|l|}{ Business characteristics } \\
\hline Number of family workers & $\begin{array}{l}1.39 \\
(0.7)\end{array}$ & $\begin{array}{c}1.48 \\
(0.8)\end{array}$ & $\begin{array}{c}1.37 \\
(0.67)\end{array}$ \\
\hline Number of hours & $\begin{array}{l}2585.73 \\
(1614.59)\end{array}$ & $\begin{array}{c}2065.16 \\
(1480.38)\end{array}$ & $\begin{array}{c}2698.74 \\
(1620.45)\end{array}$ \\
\hline Workplace: home-based & $\begin{array}{c}0.25 \\
(0.43)\end{array}$ & $\begin{array}{c}0.26 \\
(0.44)\end{array}$ & $\begin{array}{c}0.25 \\
(0.43)\end{array}$ \\
\hline Workplace: other fixed & $\begin{array}{l}0.52 \\
(0.5)\end{array}$ & $\begin{array}{c}0.4 \\
(0.49)\end{array}$ & $\begin{array}{l}0.55 \\
(0.5)\end{array}$ \\
\hline Workplace: moving & $\begin{array}{c}0.23 \\
(0.42)\end{array}$ & $\begin{array}{c}0.35 \\
(0.48)\end{array}$ & $\begin{array}{c}0.2 \\
(0.4)\end{array}$ \\
\hline
\end{tabular}




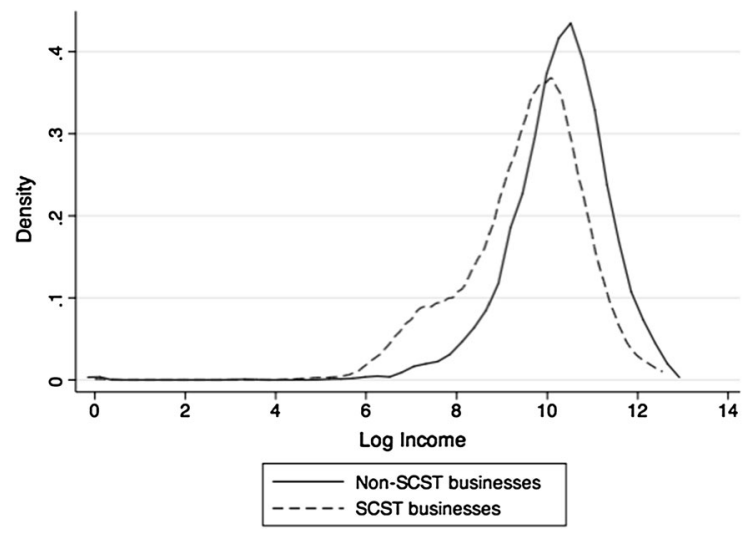

Fig. 1 Kernel density of log income

We also examine networks since these can affect the decision to become self-employed, as well as the prospective success of the business (Allen 2000). In general, participation in such networks is low. $8 \%$ of all businesses are members of business or professional groups with membership of SCST businesses being below average $(5 \%)$. Participation in credit or savings groups does not differ by caste, covering roughly $7 \%$ of owners. Membership in caste associations is 14 and $12 \%$ for non-SCST and SCST businesses, respectively. Membership in development groups and cooperatives is miniscule across the board. In terms of political networks, $12.5 \%$ of SCSTs have someone in, or close to, their household who has been an official in local bodies, while for non-SCSTs, the corresponding figure is $10.6 \% .{ }^{14}$ Overall, there is no discernible pattern in network participation of the two groups in our data.

These gaps in performance could also be related to other characteristics, such as (a) the number of family members who worked in the business: SCST businesses have greater than average number of family members working in the business (1.47), as compared to non-SCST businesses (1.37); and (b) the total number of hours put in by everyone working in the business: Non-SCST businesses record 1.3 times more hours than their SCST counterparts.

In terms of business location, about $25 \%$ of businesses are home-based, and this proportion does not differ by caste. $34 \%$ of SCSTs and $20 \%$ of nonSCSTs have mobile workplaces, while the proportions

\footnotetext{
${ }^{14}$ This could possibly reflect the operation of the mandatory $22.5 \%$ caste quotas in local bodies for SCSTs.
}

of non-SCSTs and SCSTs with fixed workplaces are 55 and 39, respectively. To the extent a fixed workplace indicates permanency, it suggests that non-SCST businesses are more stable and less makeshift.

The most important sector for these businesses is 'wholesale, retail trade and restaurants and hotels,' which include activities such as running of 'kirana' (neighborhood grocery) stores, other grocery and general stores, and petty shops. $56 \%$ of non-SCST businesses and $44.5 \%$ of SCST businesses are involved in this sector. About $13 \%$ of businesses are in manufacturing activities, and this proportion does not vary by caste. The major activities here are blacksmiths, carpenters and flour mills. About $16 \%$ of businesses are in the 'community, social and personal services' sector. This includes activities such as barbers, cycle repair shops and tailoring. These examples also corroborate our intuition that these businesses are engaged in low-end activities, and are more survivalist than entrepreneurial.

Approximately $6.5 \%$ of businesses are in the 'transport, storage and communication' sector, with the proportion being the same across castes. Overall, only $4 \%$ of businesses are in the primary sector (agriculture, hunting, forestry and fishing), but $15 \%$ of SCST businesses are in this sector. Proportions in 'construction' and 'financing, insurance, real estate and business services' are small, involving only about $2 \%$ of businesses each. Businesses engaged in 'mining and quarrying' and 'electricity, gas and water' sectors are practically non-existent, as expected, since these highly capital-intensive activities are not conducive to self-employment.

\section{Results}

\subsection{Earnings function estimates}

Table 2 reports the OLS estimates with log income as the dependent variable, for the pooled sample, and separately by caste. We present estimates using two specifications. Specification 1 uses only exogenous explanatory variables. This includes age and age squared (as proxies for experience), whether married or not, years of education, whether urban or not, and state of residence. Specification 2 is more exhaustive and also includes potentially endogenous variables. In 
Table 2 OLS estimation: pooled sample and caste-wise

\begin{tabular}{|c|c|c|c|c|c|c|}
\hline \multirow[t]{2}{*}{ Dependent variable: log income } & \multicolumn{3}{|c|}{ Specification 1} & \multicolumn{3}{|c|}{ Specification 2} \\
\hline & $\begin{array}{l}\text { (1) } \\
\text { Pooled }\end{array}$ & $\begin{array}{l}(2) \\
\text { SCST }\end{array}$ & $\begin{array}{l}\text { (3) } \\
\text { Non-SCST }\end{array}$ & $\begin{array}{l}(4) \\
\text { Pooled }\end{array}$ & $\begin{array}{l}(5) \\
\text { SCST }\end{array}$ & $\begin{array}{l}\text { (6) } \\
\text { Non-SCST }\end{array}$ \\
\hline SCST & $\begin{array}{l}-0.349 * * * \\
(0.056)\end{array}$ & & & $\begin{array}{l}-0.103 * * * \\
(0.039)\end{array}$ & & \\
\hline Age & $\begin{array}{l}0.017 * * \\
(0.008)\end{array}$ & $\begin{array}{l}0.039 * * \\
(0.016)\end{array}$ & $\begin{array}{l}0.016 * \\
(0.009)\end{array}$ & $\begin{array}{l}0.022 * * * \\
(0.007)\end{array}$ & $\begin{array}{l}0.039 * * \\
(0.016)\end{array}$ & $\begin{array}{l}0.019 * * \\
(0.008)\end{array}$ \\
\hline Age squared/100 & $\begin{array}{c}-0.017 * \\
(0.009)\end{array}$ & $\begin{array}{l}-0.038 * * \\
(0.018)\end{array}$ & $\begin{array}{l}-0.016^{*} \\
(0.010)\end{array}$ & $\begin{array}{l}-0.024 * * * \\
(0.008)\end{array}$ & $\begin{array}{l}-0.043 * * \\
(0.018)\end{array}$ & $\begin{array}{l}-0.021 * * \\
(0.009)\end{array}$ \\
\hline Married & $\begin{array}{l}0.141 * * \\
(0.056)\end{array}$ & $\begin{array}{r}-0.078 \\
(0.109)\end{array}$ & $\begin{array}{l}0.185^{* * *} \\
(0.059)\end{array}$ & $\begin{array}{c}0.060 \\
(0.051)\end{array}$ & $\begin{array}{l}-0.053 \\
(0.129)\end{array}$ & $\begin{array}{l}0.091 * \\
(0.048)\end{array}$ \\
\hline Years of education & $\begin{array}{l}0.055^{* * * *} \\
(0.004)\end{array}$ & $\begin{array}{l}0.065^{* * * *} \\
(0.010)\end{array}$ & $\begin{array}{l}0.052 * * * \\
(0.004)\end{array}$ & $\begin{array}{l}0.012 * * * \\
(0.004)\end{array}$ & $\begin{array}{c}0.011 \\
(0.008)\end{array}$ & $\begin{array}{l}0.013 * * * \\
(0.004)\end{array}$ \\
\hline Asset ownership & & & & $\begin{array}{l}0.150 * * * \\
(0.009)\end{array}$ & $\begin{array}{l}0.138 * * * \\
(0.027)\end{array}$ & $\begin{array}{l}0.151 * * * \\
(0.009)\end{array}$ \\
\hline Urban location & $\begin{array}{l}0.721 * * * \\
(0.049)\end{array}$ & $\begin{array}{l}0.768^{* * * *} \\
(0.090)\end{array}$ & $\begin{array}{l}0.707 * * * \\
(0.051)\end{array}$ & $\begin{array}{l}0.250 * * * \\
(0.036)\end{array}$ & $\begin{array}{l}0.261 * * * \\
(0.076)\end{array}$ & $\begin{array}{l}0.252 * * * \\
(0.039)\end{array}$ \\
\hline $\begin{array}{l}\text { Business or professional } \\
\text { group membership }\end{array}$ & & & & $\begin{array}{l}0.158 * * \\
(0.063)\end{array}$ & $\begin{array}{c}0.195 \\
(0.127)\end{array}$ & $\begin{array}{l}0.160 * * \\
(0.070)\end{array}$ \\
\hline $\begin{array}{l}\text { Credit or savings group } \\
\text { membership }\end{array}$ & & & & $\begin{array}{l}-0.120 * * \\
(0.048)\end{array}$ & $\begin{array}{r}-0.124 \\
(0.101)\end{array}$ & $\begin{array}{l}-0.127 * * \\
(0.057)\end{array}$ \\
\hline Caste association membership & & & & $\begin{array}{l}-0.049 \\
(0.060)\end{array}$ & $\begin{array}{l}-0.075 \\
(0.085)\end{array}$ & $\begin{array}{l}-0.054 \\
(0.072)\end{array}$ \\
\hline $\begin{array}{l}\text { Development group/NGO } \\
\text { membership }\end{array}$ & & & & $\begin{array}{c}0.067 \\
(0.080)\end{array}$ & $\begin{array}{l}0.535^{*} \\
(0.295)\end{array}$ & $\begin{array}{c}0.060 \\
(0.082)\end{array}$ \\
\hline Co-operative membership & & & & $\begin{array}{l}-0.096 \\
(0.096)\end{array}$ & $\begin{array}{r}-0.236 \\
(0.236)\end{array}$ & $\begin{array}{l}-0.095 \\
(0.102)\end{array}$ \\
\hline $\begin{array}{l}\text { Village panchayat or } \\
\text { ward committee }\end{array}$ & & & & $\begin{array}{r}-0.048 \\
(0.064)\end{array}$ & $\begin{array}{l}-0.042 \\
(0.067)\end{array}$ & $\begin{array}{l}-0.050 \\
(0.081)\end{array}$ \\
\hline Log (number of hours) & & & & $\begin{array}{l}0.552 * * * \\
(0.029)\end{array}$ & $\begin{array}{l}0.592 * * * \\
(0.054)\end{array}$ & $\begin{array}{l}0.530 * * * \\
(0.031)\end{array}$ \\
\hline Number of workers & & & & $\begin{array}{l}-0.043^{*} \\
(0.026)\end{array}$ & $\begin{array}{l}-0.077 \\
(0.051)\end{array}$ & $\begin{array}{l}-0.026 \\
(0.028)\end{array}$ \\
\hline Workplace-other fixed & & & & $\begin{array}{l}0.267 * * * \\
(0.049)\end{array}$ & $\begin{array}{l}0.262 * * * \\
(0.078)\end{array}$ & $\begin{array}{l}0.273 * * * \\
(0.055)\end{array}$ \\
\hline Workplace-moving & & & & $\begin{array}{l}0.159 * * * \\
(0.055)\end{array}$ & $\begin{array}{c}0.085 \\
(0.087)\end{array}$ & $\begin{array}{l}0.178 * * * \\
(0.061)\end{array}$ \\
\hline Constant & $\begin{array}{l}9.500 * * * \\
(0.272)\end{array}$ & $\begin{array}{l}9.975 * * * \\
(0.340)\end{array}$ & $\begin{array}{l}9.413 * * * \\
(0.303)\end{array}$ & $\begin{array}{l}5.280 * * * \\
(0.280)\end{array}$ & $\begin{array}{l}5.123 * * * \\
(0.505)\end{array}$ & $\begin{array}{l}5.507 * * * \\
(0.319)\end{array}$ \\
\hline Observations & 7271 & 1298 & 5973 & 7035 & 1252 & 5783 \\
\hline$R^{2}$ & 0.304 & 0.378 & 0.252 & 0.514 & 0.653 & 0.454 \\
\hline
\end{tabular}

Robust standard errors clustered at the district level are reported in parentheses. State of residence dummy variables is included in both specifications, whereas specification 2 also adds industry dummy variables

*** Significant at $1 \%$;* significant at $5 \%$; significant at $10 \%$ 
addition to variables in the first specification, we include the asset ownership/wealth index, memberships in: business or professional groups, credit or savings groups, caste associations, development groups, co-operatives, political networks, number of hours spent by everyone working in the business, number of family members working in the businesses, whether workplace is fixed or moving (reference category is home-based) and industry type. ${ }^{15}$

The SCST dummy is negative and significant in both specifications, indicating that ceteris paribus, belonging to these marginalized groups, is negatively correlated with income. As expected, earnings have a quadratic relationship with the decision-maker's age such that earnings initially increase with age and start to decline thereafter. Businesses operated by more educated owners also perform better indicating that more years of formal education may be associated with higher managerial ability and business acumen. Households owning more assets are able to overcome liquidity constraints more easily, and we find that asset-rich households own more profitable businesses. Businesses in urban locations perform better possibly due to proximity to markets and easier availability of information. The number of hours spent working is positively correlated with income, as expected. Businesses based on other fixed locations (outside of the home) and that are mobile are correlated with higher incomes than home-based businesses.

Pooled regressions impose the restriction that the returns to included characteristics are the same for the two caste groups. Since this assumption is not realistic, particularly in the Indian context, we also report castespecific OLS regressions. Caste-specific OLS estimates indicate that some variables-particularly those related to memberships in business or professional groups, development groups and credit groupscorrelate in different ways with performance of SCST and non-SCST businesses.

\footnotetext{
15 As a robustness check, we also estimated three specifications: one with purely personal characteristics; second with personal and household characteristics, and third one being the same as the full specification with all variables. The results, robust to alternative specifications, are available from the authors upon request.
}

\subsection{Decomposition of the mean earnings gap}

The results of the Blinder-Oaxaca decomposition with log income as the dependent variable are presented in Table 3. ${ }^{16}$ Panel A and Panel B of Table 3 display the decomposition results using specification 1 and specification 2, respectively. Within each of these panels, we report results using: coefficients from a pooled model over both groups as the reference coefficients; non-SCST coefficients, i.e., how SCST businesses would fare if they were treated like non-SCST businesses; and SCST coefficients, i.e., how nonSCSTs would fare if they were treated like SCSTs.

It is apparent that as more variables are added in moving from Panel A to Panel B, the explained proportion increases and the unexplained proportion decreases significantly. In Panel B, in the presence of non-SCST coefficients, the unexplained component is $19 \%$. Using SCST coefficients, we see that the unexplained proportion is $10.05 \%$, and for the pooled model, the corresponding value is $16 \%$. Following Banerjee and Knight (1985), we can take the geometric mean of the estimates based on the SCST coefficients and non-SCST coefficients to yield a single estimate of the unexplained component which amounts to $13.8 \%$.

Which of the variables contributes the most to the explained component? The lower panel of Table 3 shows the contribution of selected significant characteristics to the overall explained part of the income gap. Using the first specification, years of education contributes $39-42 \%$ of the explained component, depending on the counterfactual earnings structure. Urban location also accounts for 37-44\%. However, in the second specification, the importance of years of education and urban location declines significantly to around 5 and $8 \%$, respectively, and number of hours and asset ownership emerge as the dominant variables, each accounting for approximately 30-40\% of the explained component. Since variables such as years of education and urban location are generally positively correlated with asset ownership, it is not surprising that upon controlling for the latter, the relative importance of education and location declines.

\footnotetext{
16 This is done using the STATA program 'oaxaca' (Jann 2008).
} 
Table 3 Blinder-Oaxaca decomposition of log income

\begin{tabular}{|c|c|c|c|c|c|c|}
\hline & \multicolumn{3}{|c|}{ Panel A Spec. 1} & \multicolumn{3}{|c|}{ Panel B Spec. 2} \\
\hline & $\begin{array}{l}\text { Pooled } \\
\text { coefficients }\end{array}$ & $\begin{array}{l}\text { Non-SCST } \\
\text { coefficients }\end{array}$ & $\begin{array}{l}\text { SCST } \\
\text { coefficients }\end{array}$ & $\begin{array}{l}\text { Pooled } \\
\text { coefficients }\end{array}$ & $\begin{array}{l}\text { Non-SCST } \\
\text { coefficients }\end{array}$ & $\begin{array}{l}\text { SCST } \\
\text { coefficients }\end{array}$ \\
\hline Difference & $\begin{array}{l}0.667 * * * \\
(0.075)\end{array}$ & $\begin{array}{l}0.667 * * * \\
(0.075)\end{array}$ & $\begin{array}{l}0.667 * * * \\
(0.075)\end{array}$ & $\begin{array}{l}0.641 * * * \\
(0.077)\end{array}$ & $\begin{array}{l}0.641 * * * \\
(0.077)\end{array}$ & $\begin{array}{l}0.641 * * * \\
(0.077)\end{array}$ \\
\hline Explained & $\begin{array}{l}0.318^{* * * *} \\
(0.046)\end{array}$ & $\begin{array}{l}0.297 * * * \\
(0.044)\end{array}$ & $\begin{array}{l}0.389 * * * \\
(0.062)\end{array}$ & $\begin{array}{l}0.538 * * * \\
(0.067)\end{array}$ & $\begin{array}{l}0.519 * * * \\
(0.065)\end{array}$ & $\begin{array}{l}0.577 * * * \\
(0.075)\end{array}$ \\
\hline Unexplained & $\begin{array}{l}0.349 * * * \\
(0.054)\end{array}$ & $\begin{array}{l}0.369 * * * \\
(0.058)\end{array}$ & $\begin{array}{l}0.278 * * * \\
(0.054)\end{array}$ & $\begin{array}{l}0.103 * * * \\
(0.038)\end{array}$ & $\begin{array}{l}0.122 * * * \\
(0.041)\end{array}$ & $\begin{array}{c}0.064 \\
(0.045)\end{array}$ \\
\hline$\%$ Unexplained & 52.31 & 55.42 & 41.7 & 16.06 & 19.01 & 10.05 \\
\hline \multicolumn{7}{|c|}{ Contribution to explained component } \\
\hline $\begin{array}{l}\text { Years of } \\
\text { education }\end{array}$ & $\begin{array}{l}0.129 * * * \\
(0.016)\end{array}$ & $\begin{array}{l}0.124 * * * \\
(0.016)\end{array}$ & $\begin{array}{l}0.152 * * * \\
(0.028)\end{array}$ & $\begin{array}{l}0.028 * * * \\
(0.009)\end{array}$ & $\begin{array}{l}0.03 * * * \\
(0.01)\end{array}$ & $\begin{array}{c}0.025 \\
(0.017)\end{array}$ \\
\hline Urban location & $\begin{array}{l}0.134 * * * \\
(0.022)\end{array}$ & $\begin{array}{l}0.132 * * * \\
(0.022)\end{array}$ & $\begin{array}{l}0.143 * * * \\
(0.027)\end{array}$ & $\begin{array}{l}0.045^{* * * *} \\
(0.009)\end{array}$ & $\begin{array}{l}0.045^{* * * *} \\
(0.01)\end{array}$ & $\begin{array}{l}0.047 * * * \\
(0.015)\end{array}$ \\
\hline Asset ownership & & & & $\begin{array}{l}0.205^{* * *} \\
(0.021)\end{array}$ & $\begin{array}{l}0.207 * * * \\
(0.021)\end{array}$ & $\begin{array}{l}0.189 * * * \\
(0.039)\end{array}$ \\
\hline $\begin{array}{l}\text { Total person- } \\
\text { hours }\end{array}$ & & & & $\begin{array}{l}0.215^{* * *} \\
(0.037)\end{array}$ & $\begin{array}{l}0.207 * * * \\
(0.036)\end{array}$ & $\begin{array}{l}0.231 * * * \\
(0.044)\end{array}$ \\
\hline
\end{tabular}

Robust standard errors clustered at the district level in parentheses *** Significant at $1 \%$, ** significant at $5 \%$; significant at $10 \%$

\subsection{Quantile regressions}

For quantile regressions, we use the same two specifications of the earnings function that we used for the OLS regressions. The average gap in $\log$ incomes of non-SCST-owned and SCST-owned businesses is 0.75 , which corresponds to a gap of $112 \%$ in raw net incomes of the two types of businesses. This is instructive, but when we juxtapose this against the log income gap for the different quantiles, we see that restricting the analysis to only mean gaps misses a large part of the bigger picture. Broadly speaking, as Fig. 2 indicates, while the uncontrolled log income gap is positive throughout the distribution, the gap is higher for low-income businesses as compared to high-income businesses, with the gap for those at the 10th percentile (300 \%) and 25th percentile (154\%) being substantially higher than the gap at the 75th and 90th percentiles (87 and $66 \%$, respectively). This phenomenon of higher gaps at lower levels of the earnings distribution is similar to the 'sticky floor' phenomenon observed in the gender wage gap literature. Sticky floors are broadly defined as declining

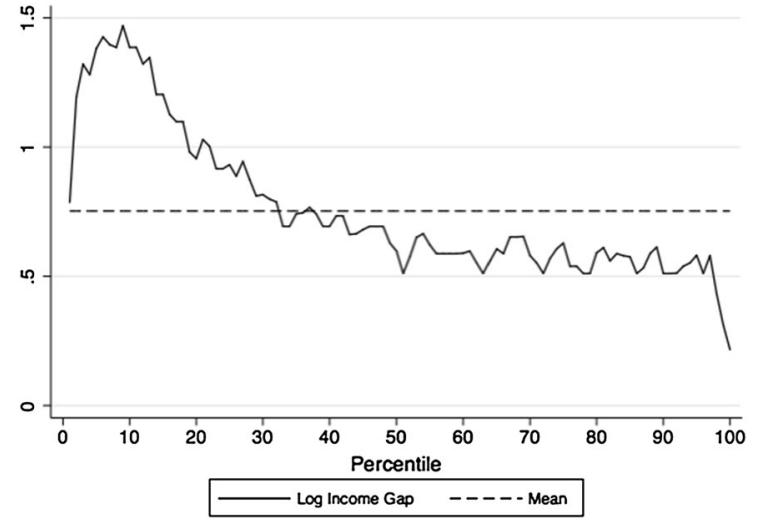

Fig. 2 Caste log income gap across percentiles and average gap earning gaps as one moves from lower to higher quantiles of the earnings distribution (e.g., Arulampalam et al. 2007). ${ }^{17}$ Unlike gender wage gaps in most developed countries that are characterized by 'glass

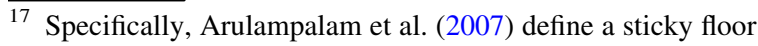
as the 10th percentile wage gap being higher than the 25 th percentile wage gap by at least two percentage points.
} 
Table 4 Quantile regression: specification 1 (pooled sample)

\begin{tabular}{|c|c|c|c|c|c|c|}
\hline & $\begin{array}{l}(1) \\
\text { Mean }\end{array}$ & $\begin{array}{l}\text { (2) } \\
\text { Q10 }\end{array}$ & $\begin{array}{l}(3) \\
\text { Q25 }\end{array}$ & $\begin{array}{l}\text { (4) } \\
\text { Q50 }\end{array}$ & $\begin{array}{l}(5) \\
\text { Q75 }\end{array}$ & $\begin{array}{l}\text { (6) } \\
\text { Q90 }\end{array}$ \\
\hline SCST & $\begin{array}{c}-0.349 * * * \\
(0.056)\end{array}$ & $\begin{array}{c}-0.532 * * * \\
(0.073)\end{array}$ & $\begin{array}{c}-0.467 * * * \\
(0.051)\end{array}$ & $\begin{array}{c}-0.368 * * * \\
(0.031)\end{array}$ & $\begin{array}{c}-0.275 * * * \\
(0.039)\end{array}$ & $\begin{array}{c}-0.266^{* * *} \\
(0.038)\end{array}$ \\
\hline Age & $\begin{array}{l}0.017 * * \\
(0.008)\end{array}$ & $\begin{array}{l}0.044 * * * \\
(0.012)\end{array}$ & $\begin{array}{l}0.038 * * * \\
(0.007)\end{array}$ & $\begin{array}{l}0.033 * * * \\
(0.012)\end{array}$ & $\begin{array}{l}0.024 * * * \\
(0.007)\end{array}$ & $\begin{array}{l}0.022 * * * \\
(0.008)\end{array}$ \\
\hline Age squared/100 & $\begin{array}{c}-0.017 * \\
(0.009)\end{array}$ & $\begin{array}{c}-0.049 * * * \\
(0.014)\end{array}$ & $\begin{array}{c}-0.044 * * * \\
(0.008)\end{array}$ & $\begin{array}{c}-0.036 * * * \\
(0.011)\end{array}$ & $\begin{array}{c}-0.022 * * * \\
(0.007)\end{array}$ & $\begin{array}{c}-0.019 * * \\
(0.008)\end{array}$ \\
\hline Married & $\begin{array}{l}0.141^{* *} \\
(0.056)\end{array}$ & $\begin{array}{c}0.132 \\
(0.085)\end{array}$ & $\begin{array}{l}0.149 * * * \\
(0.046)\end{array}$ & $\begin{array}{c}0.110 \\
(0.160)\end{array}$ & $\begin{array}{c}0.080 \\
(0.053)\end{array}$ & $\begin{array}{c}0.053 \\
(0.053)\end{array}$ \\
\hline Years of education & $\begin{array}{l}0.055^{* * *} \\
(0.004)\end{array}$ & $\begin{array}{l}0.052 * * * \\
(0.005)\end{array}$ & $\begin{array}{l}0.054 * * * \\
(0.004)\end{array}$ & $\begin{array}{l}0.054 * * * \\
(0.010)\end{array}$ & $\begin{array}{l}0.059 * * * \\
(0.003)\end{array}$ & $\begin{array}{l}0.063 * * * \\
(0.004)\end{array}$ \\
\hline Urban location & $\begin{array}{l}0.721 * * * \\
(0.049)\end{array}$ & $\begin{array}{l}0.936 * * * \\
(0.059)\end{array}$ & $\begin{array}{l}0.743 * * * \\
(0.037)\end{array}$ & $\begin{array}{l}0.599 * * * \\
(0.051)\end{array}$ & $\begin{array}{l}0.535^{* * *} \\
(0.029)\end{array}$ & $\begin{array}{l}0.491 * * * \\
(0.030)\end{array}$ \\
\hline Constant & $\begin{array}{l}9.500 * * * \\
(0.272)\end{array}$ & $\begin{array}{l}7.822 * * * \\
(0.218)\end{array}$ & $\begin{array}{l}8.680 * * * \\
(0.266)\end{array}$ & $\begin{array}{l}9.503 * * * \\
(0.179)\end{array}$ & $\begin{array}{c}10.238^{* * *} \\
(0.180)\end{array}$ & $\begin{array}{c}10.927 * * * \\
(0.207)\end{array}$ \\
\hline Observations & 7271 & 7271 & 7271 & 7271 & 7271 & 7271 \\
\hline$R^{2}$ & 0.304 & & & & & \\
\hline
\end{tabular}

Robust standard errors clustered at the district level are reported in parentheses for OLS. Quantile regression standard errors in parentheses are bootstrapped using 100 replications. State of residence dummy variables included

*** Significant at $1 \%$; * significant at $5 \%$; significant at $10 \%$

ceilings' (i.e., increasing wage gaps as one moves from lower to higher quantiles), several developing countries reveal a sticky floor, for instance India (Khanna 2013; Deshpande et al. 2015), China (Chi and Li 2008), Bangladesh (Nordman et al. 2015) and Vietnam (Pham and Reilly 2007). In fact, Carrillo et al. (2014) find that gender wage gaps in poorer and more unequal countries exhibit sticky floors, whereas glass ceilings characterize richer and less unequal ones, using a sample of 12 Latin American countries.

Tables 4 and 5 report quantile regression results for the two specifications, respectively, for the pooled model at the 10th, 25th, 50th, 75th and 90th percentiles. The estimates show that controlling for various characteristics reduces but does not eliminate the caste gap observed in Fig. 2. In Table 5, even with the most inclusive specification, the caste dummy remains negative and significant, but compared to Table 4, its magnitude is much smaller at each of the percentiles. The sticky floor no longer prevails as in Table 4 . The caste income gap increases from $10 \%$ at the 10th percentile to $16 \%$ at the median, declines to $10 \%$ at the 75 th percentile and increases again up to $14 \%$ at the 90 th percentile.
Results of caste-specific quantile regressions are reported in Tables 6 and 7. Results from Table 7 indicate that while being married and years of education are associated positively with income for non-SCSTs, they are not significant for SCSTs. Being located in urban areas and number of hours spent in the business seems to confer greater benefits at the lower end of the earnings distribution than at the higher end, for both groups. On the other hand, gains from asset ownership are mostly increasing across the distribution for both groups. Returns to other fixed or moving workplaces appear higher at all percentiles for SCSTs as compared to non-SCSTs.

\subsection{Quantile decompositions of log income gaps}

We conduct the quantile decompositions separately using both specifications. ${ }^{18}$ Table 8 shows the summary results with the raw difference, characteristics effect and coefficients effect at the 10th, 25th, 50th, 75th and 90th percentiles using the non-SCST

\footnotetext{
$\overline{18}$ This is done using the STATA program 'rqdeco' (Melly 2007).
} 
Table 5 Quantile regression: specification 2 (pooled sample)

\begin{tabular}{|c|c|c|c|c|c|c|}
\hline & $\begin{array}{l}(1) \\
\text { Mean }\end{array}$ & $\begin{array}{l}\text { (2) } \\
\text { Q10 }\end{array}$ & $\begin{array}{l}(3) \\
\text { Q25 }\end{array}$ & $\begin{array}{l}(4) \\
\text { Q50 }\end{array}$ & $\begin{array}{l}(5) \\
\text { Q75 }\end{array}$ & $\begin{array}{l}\text { (6) } \\
\text { Q90 }\end{array}$ \\
\hline SCST & $\begin{array}{c}-0.103 * * * \\
(0.039)\end{array}$ & $\begin{array}{c}-0.104 * * \\
(0.050)\end{array}$ & $\begin{array}{c}-0.115 * * * \\
(0.038)\end{array}$ & $\begin{array}{c}-0.161 * * * \\
(0.033)\end{array}$ & $\begin{array}{c}-0.103^{* * *} \\
(0.030)\end{array}$ & $\begin{array}{c}-0.141 * * * \\
(0.035)\end{array}$ \\
\hline Age & $\begin{array}{l}0.022 * * * \\
(0.007)\end{array}$ & $\begin{array}{l}0.052 * * * \\
(0.010)\end{array}$ & $\begin{array}{l}0.044 * * * \\
(0.008)\end{array}$ & $\begin{array}{l}0.021 * * * \\
(0.006)\end{array}$ & $\begin{array}{l}0.017 * * * \\
(0.005)\end{array}$ & $\begin{array}{c}0.009 \\
(0.007)\end{array}$ \\
\hline Age squared/100 & $\begin{array}{c}-0.024 * * * \\
(0.008)\end{array}$ & $\begin{array}{c}-0.060 * * * \\
(0.011)\end{array}$ & $\begin{array}{c}-0.050 * * * \\
(0.010)\end{array}$ & $\begin{array}{c}-0.024 * * * \\
(0.006)\end{array}$ & $\begin{array}{c}-0.019 * * * \\
(0.006)\end{array}$ & $\begin{array}{r}-0.010 \\
(0.007)\end{array}$ \\
\hline Married & $\begin{array}{c}0.060 \\
(0.051)\end{array}$ & $\begin{array}{l}0.172 * * * \\
(0.055)\end{array}$ & $\begin{array}{c}0.091 * \\
(0.053)\end{array}$ & $\begin{array}{l}0.105^{* *} \\
(0.043)\end{array}$ & $\begin{array}{c}0.078 * \\
(0.042)\end{array}$ & $\begin{array}{c}0.091 * \\
(0.050)\end{array}$ \\
\hline Years of education & $\begin{array}{l}0.012 * * * \\
(0.004)\end{array}$ & $\begin{array}{l}0.018 * * * \\
(0.005)\end{array}$ & $\begin{array}{l}0.011 * * * \\
(0.003)\end{array}$ & $\begin{array}{l}0.012 * * * \\
(0.003)\end{array}$ & $\begin{array}{l}0.016 * * * \\
(0.003)\end{array}$ & $\begin{array}{l}0.017 * * * \\
(0.004)\end{array}$ \\
\hline Asset ownership & $\begin{array}{l}0.150 * * * \\
(0.009)\end{array}$ & $\begin{array}{l}0.118^{* * *} \\
(0.011)\end{array}$ & $\begin{array}{l}0.136 * * * \\
(0.009)\end{array}$ & $\begin{array}{l}0.150 * * * \\
(0.006)\end{array}$ & $\begin{array}{l}0.170 * * * \\
(0.006)\end{array}$ & $\begin{array}{l}0.169 * * * \\
(0.009)\end{array}$ \\
\hline Urban location & $\begin{array}{l}0.250 * * * \\
(0.036)\end{array}$ & $\begin{array}{l}0.321 * * * \\
(0.040)\end{array}$ & $\begin{array}{l}0.268 * * * \\
(0.027)\end{array}$ & $\begin{array}{l}0.227 * * * \\
(0.024)\end{array}$ & $\begin{array}{l}0.197 * * * \\
(0.024)\end{array}$ & $\begin{array}{l}0.189 * * * \\
(0.032)\end{array}$ \\
\hline Business or professional group membership & $\begin{array}{l}0.158 * * \\
(0.063)\end{array}$ & $\begin{array}{l}0.117 * * \\
(0.059)\end{array}$ & $\begin{array}{c}0.060 \\
(0.053)\end{array}$ & $\begin{array}{l}0.132 * * * \\
(0.038)\end{array}$ & $\begin{array}{l}0.095 * * \\
(0.043)\end{array}$ & $\begin{array}{l}0.169 * * * \\
(0.047)\end{array}$ \\
\hline Credit or savings group membership & $\begin{array}{c}-0.120^{* *} \\
(0.048)\end{array}$ & $\begin{array}{r}-0.060 \\
(0.056)\end{array}$ & $\begin{array}{c}-0.101 * * \\
(0.051)\end{array}$ & $\begin{array}{c}-0.156^{* * * *} \\
(0.042)\end{array}$ & $\begin{array}{c}-0.168 * * * \\
(0.043)\end{array}$ & $\begin{array}{c}-0.192 * * * \\
(0.066)\end{array}$ \\
\hline Caste association membership & $\begin{array}{c}-0.049 \\
(0.060)\end{array}$ & $\begin{array}{r}-0.023 \\
(0.057)\end{array}$ & $\begin{array}{c}0.002 \\
(0.050)\end{array}$ & $\begin{array}{c}0.044 \\
(0.036)\end{array}$ & $\begin{array}{c}0.058 * \\
(0.034)\end{array}$ & $\begin{array}{c}0.048 \\
(0.046)\end{array}$ \\
\hline Development group/NGO membership & $\begin{array}{c}0.067 \\
(0.080)\end{array}$ & $\begin{array}{l}0.273 * * \\
(0.114)\end{array}$ & $\begin{array}{c}0.118 \\
(0.091)\end{array}$ & $\begin{array}{c}0.008 \\
(0.080)\end{array}$ & $\begin{array}{c}0.041 \\
(0.077)\end{array}$ & $\begin{array}{r}-0.013 \\
(0.087)\end{array}$ \\
\hline Co-operative membership & $\begin{array}{r}-0.096 \\
(0.096)\end{array}$ & $\begin{array}{r}-0.173 \\
(0.106)\end{array}$ & $\begin{array}{r}-0.118 \\
(0.095)\end{array}$ & $\begin{array}{r}-0.020 \\
(0.070)\end{array}$ & $\begin{array}{l}-0.039 \\
(0.074)\end{array}$ & $\begin{array}{c}0.124 * \\
(0.075)\end{array}$ \\
\hline Village panchayat or ward committee & $\begin{array}{c}-0.048 \\
(0.064)\end{array}$ & $\begin{array}{c}-0.060 \\
(0.070)\end{array}$ & $\begin{array}{c}0.010 \\
(0.037)\end{array}$ & $\begin{array}{c}-0.009 \\
(0.034)\end{array}$ & $\begin{array}{c}0.004 \\
(0.037)\end{array}$ & $\begin{array}{c}-0.026 \\
(0.048)\end{array}$ \\
\hline Log (number of hours) & $\begin{array}{l}0.552 * * * \\
(0.029)\end{array}$ & $\begin{array}{l}0.686^{* * * *} \\
(0.030)\end{array}$ & $\begin{array}{l}0.634 * * * \\
(0.022)\end{array}$ & $\begin{array}{l}0.537 * * * \\
(0.021)\end{array}$ & $\begin{array}{l}0.416 * * * \\
(0.023)\end{array}$ & $\begin{array}{l}0.325^{* * * *} \\
(0.027)\end{array}$ \\
\hline Number of workers & $\begin{array}{c}-0.043^{*} \\
(0.026)\end{array}$ & $\begin{array}{c}-0.146^{* * *} \\
(0.037)\end{array}$ & $\begin{array}{c}-0.102 * * * \\
(0.022)\end{array}$ & $\begin{array}{c}-0.060 * * * \\
(0.019)\end{array}$ & $\begin{array}{r}-0.026 \\
(0.022)\end{array}$ & $\begin{array}{c}0.003 \\
(0.018)\end{array}$ \\
\hline Workplace-other fixed & $\begin{array}{l}0.267 * * * \\
(0.049)\end{array}$ & $\begin{array}{l}0.320^{* * *} \\
(0.049)\end{array}$ & $\begin{array}{l}0.274 * * * \\
(0.033)\end{array}$ & $\begin{array}{l}0.240 * * * \\
(0.030)\end{array}$ & $\begin{array}{l}0.125 * * * \\
(0.031)\end{array}$ & $\begin{array}{l}0.116 * * * \\
(0.039)\end{array}$ \\
\hline Workplace-moving & $\begin{array}{l}0.159 * * * \\
(0.055)\end{array}$ & $\begin{array}{l}0.279 * * * \\
(0.056)\end{array}$ & $\begin{array}{l}0.189 * * * \\
(0.038)\end{array}$ & $\begin{array}{l}0.163 * * * \\
(0.036)\end{array}$ & $\begin{array}{c}0.005 \\
(0.031)\end{array}$ & $\begin{array}{c}-0.010 \\
(0.045)\end{array}$ \\
\hline Constant & $\begin{array}{l}5.280 * * * \\
(0.280)\end{array}$ & $\begin{array}{l}2.589 * * * \\
(0.332)\end{array}$ & $\begin{array}{l}3.840 \text { *** } \\
(0.263)\end{array}$ & $\begin{array}{l}5.517 * * * \\
(0.234)\end{array}$ & $\begin{array}{l}7.246 * * * \\
(0.199)\end{array}$ & $\begin{array}{l}8.376^{* * * *} \\
(0.255)\end{array}$ \\
\hline Observations & 7035 & 7035 & 7035 & 7035 & 7035 & 7035 \\
\hline$R^{2}$ & 0.514 & & & & & \\
\hline
\end{tabular}

Robust standard errors clustered at the district level are reported in parentheses for OLS. Quantile regression standard errors in parentheses are bootstrapped using 100 replications. State of residence and industry dummy variables included

*** Significant at $1 \%$; * significant at $5 \%$; significant at $10 \%$ 


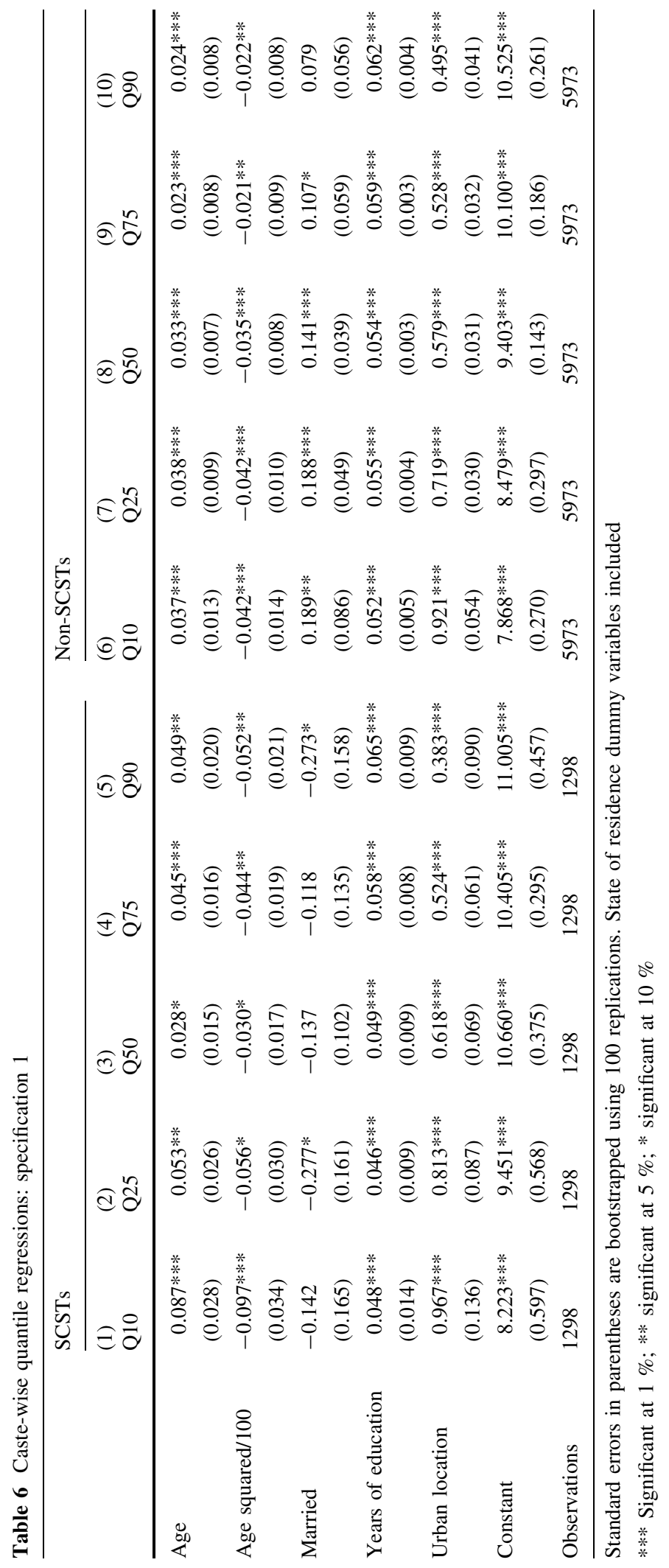




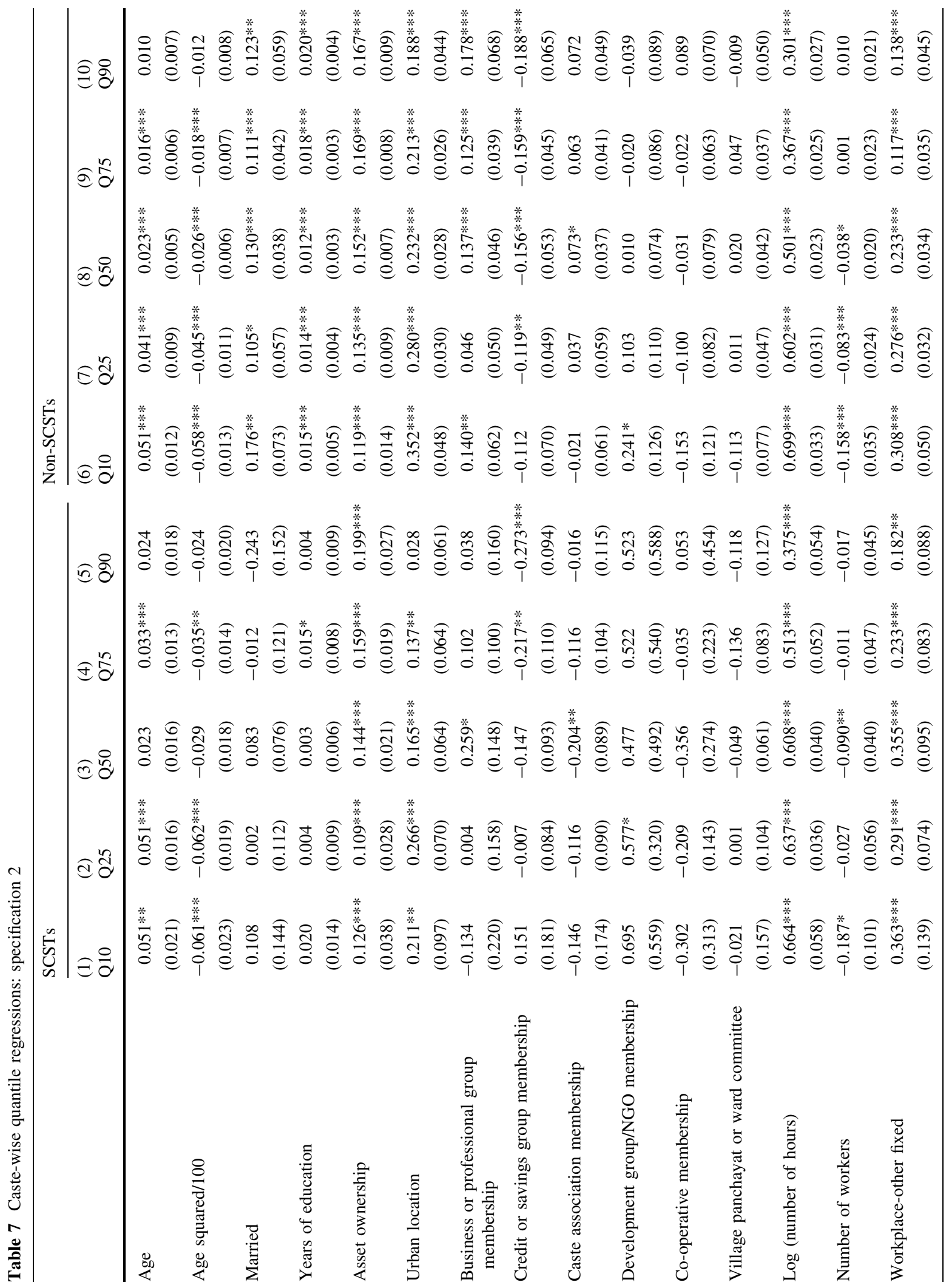




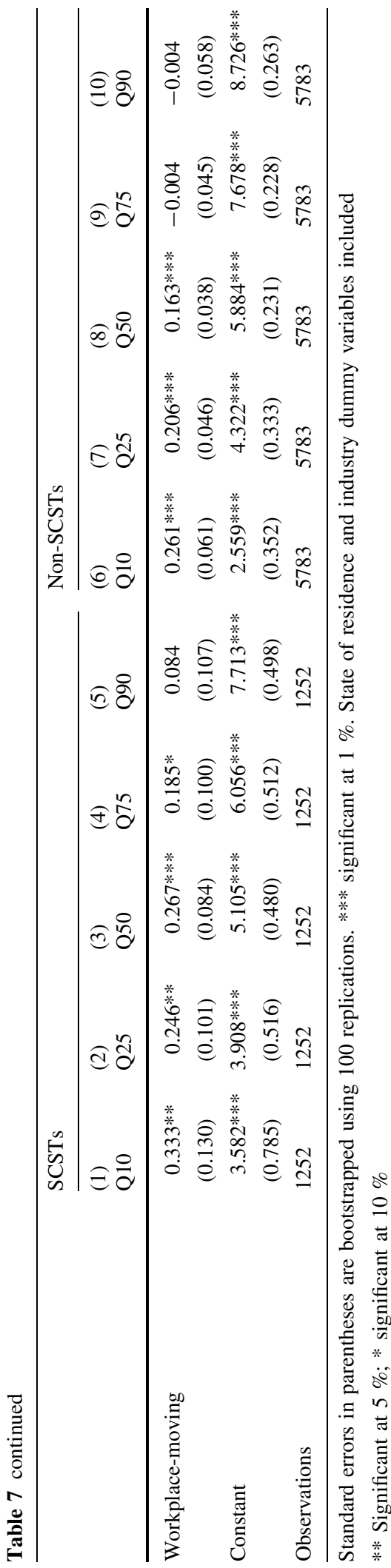

coefficients. As noted previously, another set of estimates could be obtained using the SCST coefficients (Table 9).

In both Tables 8 and 9, as with the mean decomposition, we note that upon including more explanatory variables in specification 2, the proportion explained increases. Based on non-SCST coefficients and focusing our attention on specification 2 (Table 8), we find that the raw log income gap shows a generally declining trend, first decreasing from 0.95 at the 10th percentile to 0.57 at the median and then remaining fairly flat thereafter. The proportion of the income gap due to differences in characteristics lies in the range of $84-87 \%$ and then increases to about $91 \%$ at the 90th percentile. Using the SCST coefficients (Table 9), the proportion explained is slightly lower. Differences in characteristics account for about $70 \%$ of the gap at the 10th and 25 th percentiles, $77 \%$ at the median and $82 \%$ at the 90th percentile.

Mirroring these trends, we find using both counterfactuals that the unexplained component is somewhat larger at the lower end of the conditional earnings distribution than at the higher end. In Table 8, using the second specification, the unexplained share declines from $12 \%$ at the 10th percentile to approximately $8 \%$ at the 90th percentile. While with the non-SCST earnings structure, the coefficients effect is significant for the businesses in the middle range of the earnings distribution (median and third quartile), with the SCST earnings structure, the unexplained component is statistically significant throughout the distribution.

Figures 3 and 4 plot the raw gap, the contribution of characteristics and that of coefficients at each percentile of the earnings distribution using the second specification for the non-SCST and SCST coefficients, respectively.

\section{Discussion}

As mentioned earlier, the unexplained component is the residual gap that remains after all characteristics are accounted for. It measures the influence of other unmeasured and unobserved factors, including discrimination. For instance, the IHDS data do not contain information on family background in running an enterprise, type of customer base, risk aversion of the owner, etc., all of which previous literature has shown to affect enterprise performance. Similarly, 
Table 8 Quantile decompositions of log income (non-SCST coefficients)

\begin{tabular}{|c|c|c|c|c|c|c|}
\hline \multirow[t]{2}{*}{ Decile } & \multicolumn{3}{|l|}{ Panel A Spec. 1} & \multicolumn{3}{|l|}{ Panel B Spec. 2} \\
\hline & Col. 1 difference & $\begin{array}{l}\text { Col. } 2 \\
\text { characteristics }\end{array}$ & Col 3. coefficients & Col. 4 difference & $\begin{array}{l}\text { Col. } 5 \\
\text { characteristics }\end{array}$ & Col. 6 coefficients \\
\hline 10 & $\begin{array}{l}0.999 * * * \\
(0.045)\end{array}$ & $\begin{array}{l}0.539 * * * \\
(0.093)\end{array}$ & $\begin{array}{l}0.460 * * * \\
(0.098)\end{array}$ & $\begin{array}{l}0.949 * * * \\
(0.043)\end{array}$ & $\begin{array}{l}0.829 * * * \\
(0.062)\end{array}$ & $\begin{array}{c}0.12 \\
(0.096)\end{array}$ \\
\hline 25 & $\begin{array}{l}0.765^{* * *} \\
(0.024)\end{array}$ & $\begin{array}{l}0.394 * * * \\
(0.059)\end{array}$ & $\begin{array}{l}0.371 * * * \\
(0.063)\end{array}$ & $\begin{array}{l}0.713^{* * *} \\
(0.025)\end{array}$ & $\begin{array}{l}0.615^{* * *} \\
(0.043)\end{array}$ & $\begin{array}{c}0.098 \\
(0.069)\end{array}$ \\
\hline 50 & $\begin{array}{l}0.604 * * * \\
(0.017)\end{array}$ & $\begin{array}{l}0.310 * * * \\
(0.046)\end{array}$ & $\begin{array}{l}0.294 * * * \\
(0.042)\end{array}$ & $\begin{array}{l}0.568 * * * \\
(0.018)\end{array}$ & $\begin{array}{l}0.479 * * * \\
(0.038)\end{array}$ & $\begin{array}{c}0.089 * \\
(0.052)\end{array}$ \\
\hline 75 & $\begin{array}{l}0.548 * * * \\
(0.016)\end{array}$ & $\begin{array}{l}0.321 * * * \\
(0.044)\end{array}$ & $\begin{array}{l}0.227 * * * \\
(0.036)\end{array}$ & $\begin{array}{l}0.554 * * * \\
(0.019)\end{array}$ & $\begin{array}{l}0.473 * * * \\
(0.042)\end{array}$ & $\begin{array}{c}0.081 * \\
(0.042)\end{array}$ \\
\hline 90 & $\begin{array}{l}0.546^{* * *} \\
(0.019)\end{array}$ & $\begin{array}{l}0.315^{* * *} \\
(0.052)\end{array}$ & $\begin{array}{l}0.231 * * * \\
(0.045)\end{array}$ & $\begin{array}{l}0.569 * * * \\
(0.021)\end{array}$ & $\begin{array}{l}0.522 * * * \\
(0.049)\end{array}$ & $\begin{array}{c}0.047 \\
(0.051)\end{array}$ \\
\hline
\end{tabular}

Standard errors in parentheses are based on bootstrapping with 100 replications

*** Significant at $1 \%$; * significant at $5 \%$; significant at $10 \%$

Table 9 Quantile decompositions of log income (SCST coefficients)

\begin{tabular}{|c|c|c|c|c|c|c|}
\hline \multirow[t]{2}{*}{ Decile } & \multicolumn{3}{|l|}{ Panel A Spec. 1} & \multicolumn{3}{|l|}{ Panel B Spec. 2} \\
\hline & Col. 1 difference & $\begin{array}{l}\text { Col. } 2 \\
\text { characteristics }\end{array}$ & Col 3. coefficients & Col. 4 difference & $\begin{array}{l}\text { Col. } 5 \\
\text { characteristics }\end{array}$ & Col. 6 coefficients \\
\hline \multirow[t]{2}{*}{10} & $0.999 * * *$ & $0.25 * * *$ & $0.749 * * *$ & $0.949 * * *$ & $0.663 * * *$ & $0.286 * * *$ \\
\hline & $(0.098)$ & $(0.054)$ & $(0.045)$ & $(0.096)$ & $(0.077)$ & $(0.043)$ \\
\hline \multirow[t]{2}{*}{25} & $0.765 * * *$ & $0.277 * * *$ & $0.488 * * *$ & $0.713 * * *$ & $0.491 * * *$ & $0.222 * * *$ \\
\hline & $(0.063)$ & $(0.037)$ & $(0.024)$ & $(0.069)$ & $(0.049)$ & $(0.025)$ \\
\hline \multirow[t]{2}{*}{50} & $0.604 * * *$ & $0.304 * * *$ & $0.3 * * *$ & $0.568 * * *$ & $0.44 * * *$ & $0.128 * * *$ \\
\hline & $(0.042)$ & $(0.028)$ & $(0.017)$ & $(0.052)$ & $(0.035)$ & $(0.018)$ \\
\hline \multirow[t]{2}{*}{75} & $0.548 * * *$ & $0.303 * * *$ & $0.245 * * *$ & $0.554 * * *$ & $0.467 * * *$ & $0.087 * * *$ \\
\hline & $(0.036)$ & $(0.026)$ & $(0.016)$ & $(0.042)$ & $(0.034)$ & $(0.019)$ \\
\hline \multirow[t]{2}{*}{90} & $0.546 * * *$ & $0.296 * * *$ & $0.25 * * *$ & $0.569 * * *$ & $0.469 * * *$ & $0.10 * * *$ \\
\hline & $(0.045)$ & $(0.028)$ & $(0.019)$ & $(0.051)$ & $(0.031)$ & $(0.021)$ \\
\hline
\end{tabular}

Standard errors in parentheses are based on bootstrapping with 100 replications

*** Significant at $1 \%$; * significant at $5 \%$; significant at $10 \%$

there are characteristics such as ability or motivation, which cannot be measured but can affect the earnings gap. Similarly, as noted earlier, the explained component could include pre-market discrimination.

While we cannot test empirically the channels through which discrimination manifests itself, there exist studies that qualitatively document the presence of active discrimination against SCST businesses. Prakash (2010) in his 2006-2007 survey of 90 Dalit businesses in 13 districts spread across 6 states in India reports difficulty in obtaining initial formal credit in order to set up an enterprise, resulting in informal loans being taken at high interest rates. The ones who did successfully obtain institutional credit were those in partnerships with upper castes or had local political contacts that facilitated loan approvals. Kumar (2013) using data from the 2002-2003 All-India Debt and Investment Survey finds that public sector banks 


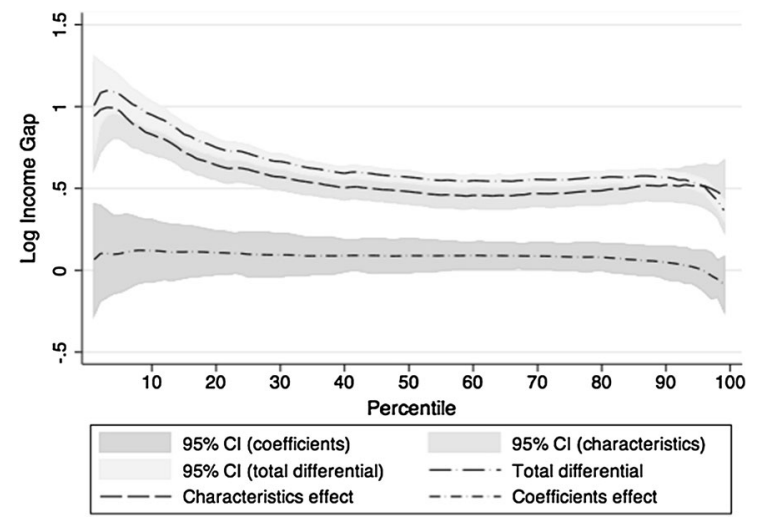

Fig. 3 Quantile decomposition of log income gap: non-SCST coefficients

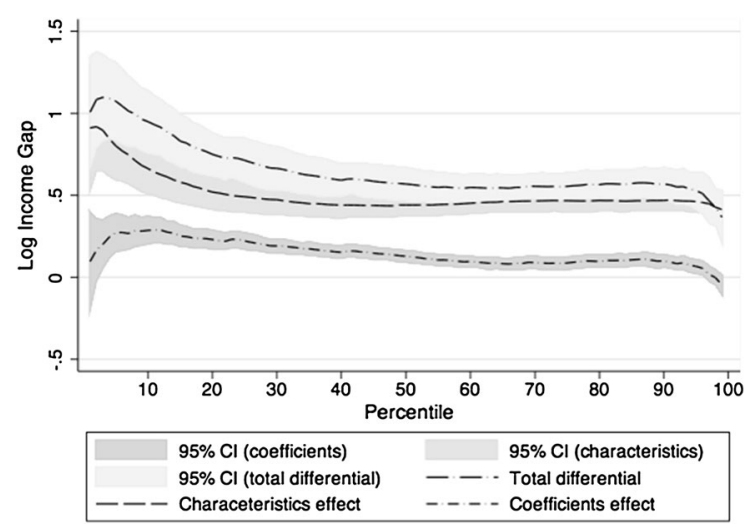

Fig. 4 Quantile decomposition of log income gap: SCST coefficients

operating in areas with more upper castes tend to discriminate more against low-caste loan applicants. Prakash (2010) also cites Dalit entrepreneurs who reported often charging less for their products than their upper-caste peers so that customers 'forget' their castes. Jodhka (2010) through detailed interviews with Dalit entrepreneurs in two towns in northwest India finds that caste works as a direct and indirect barrier in the successful running of their businesses. Most of them report difficulties on account of their Dalit identity in mobilizing finance and getting a space to start their enterprise. A majority of them felt that their caste identity was perceived as more important than their professional identity, which led to them being seen as 'odd actors' in the local community.
Another unobserved factor that could constrain enterprise performance is geographical segregation. Residential segregation is still prevalent in India with Dalits living in their own segregated neighborhoods. If the main customer base of SCST enterprises is their own community-and given that SCSTs are on average poorer and have lower purchasing powerthey may have to keep their prices low in order to cater to members of their own group. For example, Clark and Drinkwater (2000) explain that ethnic enclaves can be a source of advantage or disadvantage. While on the one hand, a concentration of co-ethnics provides a captive market for producing ethnic goods that hold particular appeal for the community, on the other hand, if the ethnic group is poor, then businesses setup by members of these groups may actually languish.

\section{Conclusion}

In this paper, our objective has been to assess the presence of caste-based discrimination in small household businesses using the large-scale nationally representative India Human Development Survey of 2004-2005. Our results show that SCST businesses fare significantly worse in terms of owner's education, household economic status and business characteristics, as compared to their non-SCST counterparts. Using the non-SCST counterfactual earnings structure, at least $20 \%$ of the mean earnings gap between businesses owned by SCSTs and non-SCSTs cannot be explained by differences in characteristics. Further, we find that there is substantial heterogeneity in raw earnings gaps across the earnings distribution revealing a sticky floor, thereby necessitating the use of quantile regression-based decomposition methods. These indicate that the proportion of the earnings gap on account of differences in characteristics is generally increasing in the higher deciles of the conditional earnings distribution.

This paper focuses on one part of the IHDS data set, viz., data related to household non-farm business, where we see clear evidence of caste-based disparities in earnings and other business characteristics, as well as the existence of discrimination. Desai and Dubey's 
(2011) analysis based on the entire IHDS data set suggests that our findings fit into the larger pattern of persistence of caste inequalities, which results in inequalities in opportunities as well as inequalities in outcomes. They find an increase in civic and political participation by marginalized groups, but also document how economic and educational disparities continue to flourish.

In addition to being the first to examine this question for India, this paper's findings confirm patterns that have been observed in the context of racial and ethnic differences in entrepreneurship in other countries such as the USA and UK. However, unlike the USA, for instance, where a number of migrant groups such as the Koreans and Japanese have used self-employment as a way to achieve upward economic and social mobility that does not appear to be the case for India, as suggested by our findings and also those in Iyer et al. (2013) and Deshpande and Sharma (2013). This also suggests that the exuberance surrounding Dalit Capitalism may be somewhat misplaced since the reality of most SC and ST businesses is in stark contrast to the success of a few Dalit billionaires.

The simultaneous existence of discrimination against SCs and STs in self-employment and wage employment presents serious challenges for public policy, further complicated by the existence of 'premarket' discrimination for Dalits which results in lower and poorer quality of educational and skill attainment. While caste-based job quotas in India target public sector-salaried employment, that may not be the appropriate instrument to tackle discrimination faced by the self-employed. One such recent move is a 2012 public procurement policy for micro- and small enterprises (MSE) that mandates $4 \%$ of government procurement to be from MSEs owned by SCs and STs. Other multi-pronged measures, based on more research, need to be devised that would tackle discrimination in both spheres. For instance, looking at the entrepreneurial success of migrant groups in countries such as the USA and UK indicates that Fairlie's (2006) suggestion of stimulating business creation in sectors with high growth potential (e.g., construction, wholesale trade and business service) might be one effective element of public policy for promoting job creation and increasing earnings, especially in areas where marginalized groups are concentrated.

A larger question is the relationship between earnings and wealth, and whether an increase in earnings (from businesses and elsewhere) is sufficient to close the wealth gap between communities. Barsky et al. (2002) find that roughly two-thirds of the mean difference in wealth between blacks and whites in the USA can be explained by differences in earnings from all sources, which suggests that substantial wealth gaps remain even after controlling for earning differences. Whether an increase in business ownership by SCs and STs translates into narrowing wealth gaps would have to be the subject matter of a future exercise.

Acknowledgments We are grateful to Deepti Goel and two anonymous referees for detailed comments; to Shantanu Khanna for discussions on the quantile regression decomposition methodology; and to seminar participants at Delhi School of Economics, Brown University, New Delhi office of the World Bank, UNU-WIDER, Nordic Conference on Development Economics 2014, IEA-World Bank Roundtable on Shared Prosperity, and the IHDS-NCAER 2014 conference on 'Human Development in India: evidence from IHDS' where earlier versions of the paper were presented, for useful comments. We are responsible for all remaining errors and omissions.

\section{Compliance with ethical standards}

Conflict of interest The authors declare that they have no conflict of interest.

\section{Appendix 1}

In order to canvass data on non-farm businesses, the survey explicitly asks 'Does any- body in this household run their own business, however big or small? Does anybody make something for sale, such as cloth or some food like pickles? Or does anybody sell something in a market or to customers of any sort? Or does anybody provide a service to others for a price, either a skilled service like a doctor or an unskilled service like a barber?'

1. Net income: gross receipts less hired workers' wages less all other expenses such as costs of materials, rent, interest on loans, etc. 
2. Age: in years (of the de facto decision-maker)

3. Marital status: equals 1 if married, 0 otherwise (of the de facto decision-maker)

4. Years of education: standard number of years of education completed (of the de facto decisionmaker)

5. Urban: equals 1 if household is in an urban area, 0 otherwise

6. Business or professional group membership: equals 1 if the household is a member, 0 otherwise

7. Credit or savings group membership: equals 1 if the household is a member, 0 otherwise

8. Caste association membership: equals 1 if the household is a member, 0 otherwise

9. Development group/NGO membership: equals 1 if the household is a member, 0 otherwise

10. Co-operative membership: equals 1 if the household is a member, 0 otherwise

11. Village panchayat or ward committee: equals 1 if someone in, or close to the household is a member, 0 otherwise

12. Total number of hours: total number of hours spent in the business by all household members involved in the business
13. Number of workers: number of household members that worked in the business

14. Workplace type: dummy variables for each of the three categories-home; other fixed place; other moving place

15. Industry type (NIC-1987): dummy variables for each of the nine categories-agriculture, hunting, forestry, fishing; mining and quarrying; manufacturing; electricity, gas and water; construction; wholesale trade, retail trade, restaurants and hotels; transport, storage and communication; finance, insurance, real estate and business services; community, social and personal services.

16. State: dummy variables for each of the 22 states-Jammu and Kashmir, Himachal Pradesh, Punjab, Uttaranchal, Haryana, Delhi, Rajasthan, Uttar Pradesh, Bihar, Tripura, Assam, West Bengal, Jharkhand, Orissa, Chhattisgarh, Madhya Pradesh, Gujarat, Maharashtra, Andhra Pradesh, Karnataka, Kerala and Tamil Nadu.

\section{Appendix 2}

See Table 10.

Table 10 Blinder-Oaxaca decomposition of log income using the sample of female-run businesses

\begin{tabular}{|c|c|c|c|c|c|c|}
\hline & \multicolumn{3}{|c|}{ Panel A Spec. 1} & \multicolumn{3}{|c|}{ Panel B Spec. 2} \\
\hline & $\begin{array}{l}\text { Pooled } \\
\text { coefficients }\end{array}$ & $\begin{array}{l}\text { Non-SCST } \\
\text { coefficients }\end{array}$ & $\begin{array}{l}\text { SCST } \\
\text { coefficients }\end{array}$ & $\begin{array}{l}\text { Pooled } \\
\text { coefficients }\end{array}$ & $\begin{array}{l}\text { Non-SCST } \\
\text { coefficients }\end{array}$ & $\begin{array}{l}\text { SCST } \\
\text { coefficients }\end{array}$ \\
\hline Difference & $\begin{array}{l}0.525 * * * \\
(0.131)\end{array}$ & $\begin{array}{l}0.525^{* * * *} \\
(0.131)\end{array}$ & $\begin{array}{l}0.525^{* * *} \\
(0.131)\end{array}$ & $\begin{array}{l}0.529 * * * \\
(0.134)\end{array}$ & $\begin{array}{l}0.529 * * * \\
(0.134)\end{array}$ & $\begin{array}{l}0.529 * * * \\
(0.134)\end{array}$ \\
\hline Explained & $\begin{array}{l}0.296 * * * \\
(0.072)\end{array}$ & $\begin{array}{l}0.281 * * * \\
(0.074)\end{array}$ & $\begin{array}{l}0.349 * * * \\
(0.097)\end{array}$ & $\begin{array}{l}0.364 * * * \\
(0.11)\end{array}$ & $\begin{array}{l}0.364 * * * \\
(0.11)\end{array}$ & $\begin{array}{l}0.401 * * * \\
(0.132)\end{array}$ \\
\hline Unexplained & $\begin{array}{l}0.229 * * \\
(0.116)\end{array}$ & $\begin{array}{l}0.244 * * \\
(0.119)\end{array}$ & $\begin{array}{l}0.176 \\
(0.12)\end{array}$ & $\begin{array}{c}0.165 * \\
(0.088)\end{array}$ & $\begin{array}{c}0.165 * \\
(0.091)\end{array}$ & $\begin{array}{c}0.128 \\
(0.111)\end{array}$ \\
\hline$\%$ Unexplained & 43.54 & 46.41 & 33.59 & 31.16 & 31.28 & 24.19 \\
\hline Observations & 1073 & & & 1039 & & \\
\hline
\end{tabular}

Robust standard errors clustered at the district level in parentheses

*** Significant at $1 \%$; * significant at $5 \%$; significant at $10 \%$ 


\section{References}

Ahn, T. (2011). Racial differences in self-employment exits. Small Business Economics, 36, 169-186.

Allen, W. D. (2000). Social networks and self-employment. Journal of Socio-Economics, 29, 487-501.

Altonji, J. G., \& Blank, R. M. (1999). Race and gender in the labor market. In O. Ashenfelter \& D. Card (Eds.), Handbook of labor economics (1st ed., Vol. 3, pp. 3143-3259). Amsterdam: Elsevier.

Antecol, H., \& Bedard, K. (2004). The racial wage gap: The importance of labor force attachment differences across Black, Mexican, and White Men. Journal of Human Resources, 39(2), 564-583.

Arulampalam, W., Booth, A. L., \& Bryan, M. L. (2007). Is there a glass ceiling over Europe? Exploring the gender pay gap across the wage distribution. Industrial and Labor Relations Review, 60(2), 163-186.

Asiedu, E., Freeman, J. A., \& Nti-Addae, A. (2012). Access to credit by small businesses: How relevant and race, ethnicity and gender. American Economic Review: Papers and Proceedings, 102(3), 532-537.

Atal, J. P., Nopo, H., \& Winder, N. (2009). New century, old disparities gender and ethnic wage gaps in Latin America. IDB Working Paper No. 109.

Audretsch, D. B., Bonte, W., \& Tamvada, J. P. (2013). Religion, social class, and entrepreneurial choice. Journal of Business Venturing, 28, 774-789.

Banerjee, B., \& Knight, J. B. (1985). Caste in Indian urban labour market. Journal of Development Economics, 17, 277-307.

Barsky, R., Bound, J., Charles, K. K., \& Lupton, J. P. (2002). Accounting for the black-white wealth gap: A nonparametric approach. Journal of the American Statistical Association, 97, 663-673.

Blanchflower, D. G., Levine, P. B., \& Zimmerman, D. J. (2003). Discrimination in the small-business credit market. Review of Economics and Statistics, 85(4), 930-943.

Blinder, A. S. (1973). Wage discrimination: Reduced form and structural estimates. Journal of Human Resources, 8, 436-455.

Borjas, G., \& Bronars, S. (1989). Consumer discrimination and self-employment. Journal of Political Economy, 97, 581-605.

Carrillo, P., Gandelman, N., \& Robano, V. (2014). Sticky floors and glass ceilings in Latin America. Journal of Economic Inequality, 12(3), 339-361.

Chi, W., \& Li, B. (2008). Glass ceiling or sticky floor? Examining the gender earnings differential across the earnings distribution in urban China, 1987-2004. Journal of Comparative Economics, 36(2), 243-263.

Clark, K., \& Drinkwater, S. (2000). Pushed out or pulled in? Self-employment among ethnic minorities in England and Wales. Labour Economics, 7, 603-628.

Coate, S., \& Tennyson, S. (1992). Labor market discrimination, imperfect information and self-employment. Oxford Economic Papers, 44, 272-288.

Cotton, J. (1988). On the decomposition of wage differentials. Review of Economics and Statistics, 70, 236-243.
Das, M. B., \& Dutta, P. (2007). Does caste matter for wages in the Indian labour market?. Washington, DC, USA: The World Bank.

Desai, S., \& Dubey, A. (2011). Caste in 21st century India: Competing narratives. Economic and Political Weekly, XLVI(11), 40-49.

Deshpande, A. (2011). The grammar of caste: Economic discrimination in con-temporary India. New Delhi: Oxford University Press.

Deshpande, A., Goel, D., \& Khanna, S. (2015). Bad karma or discrimination? Male-female wage gaps among salaried workers in India. Centre for Development Economics Working Paper 243, Delhi School of Economics.

Deshpande, A., \& Sharma, S. (2013). Entrepreneurship or survival? Caste and gender of small business in India. Economic and Political Weekly, XLVIII(28), 38-49.

Dunn, T. A., \& Holtz-Eakin, D. J. (2000). Financial capital, human capital, and the transition to self-employment: Evidence from intergenerational links. Journal of Labor Economics, 18(2), 282-305.

Fairlie, R. (2004). Racial trends in ethnic and racial business ownership. Small Business Economics, 23, 203-218.

Fairlie, R. (2006). Entrepreneurship among disadvantaged groups: An analysis of the dynamics of self-employment by gender, race and education. In Simon C. Parker, Zoltan J. Acs, \& David R. Audretsch (Eds.), International handbook series on en-trepreneurship (Vol. 2). New York: Springer.

Filmer, D., \& Pritchett, L. (2001). Estimating wealth effect without expenditure data-or tears: An application to educational enrollments in states of India. Demography, 38, $115-132$.

Fortin, N., Lemiuex, T., \& Firpo, S. (2011). Decomposition methods in economics. In Orley Ashenfelter \& David Card (Eds.), Handbook of labor economics (Vol. 4a). Amsterdam: Elsevier.

Hout, M., \& Rosen, H. (2000). Self-employment, family background, and race. Journal of Human Resources, 35(4), 670-692.

Iyer, L., Khanna, T., \& Varshney, A. (2013). Caste and entrepreneurship in India. Economic and Political Weekly, XLVIII(6), 52-60.

Jann, B. (2008). The Blinder-Oaxaca decomposition for linear regression models. STATA Journal, 8(4), 453-479.

Jodhka, S. (2010). Dalits in business: Self-employed Scheduled Castes in Northwest India. Indian Institute of Dalit Studies Working Paper, 4(2).

Karunakaran, N. (2009). Bite the caste bullet. Outlook Business, May 2.

Khanna, S. (2013). Gender wage discrimination in India: glass ceiling or sticky floor. Centre for Development Economics Working Paper 214, Delhi School of Economics.

Kumar, S. M. (2013). Does access to formal agricultural credit depend on caste? World Development, 43, 315-328.

Lofstrom, M., \& Bates, T. (2013). African Americans' pursuit of self-employment. Small Business Economics, 40, 73-86.

Machado, J., \& Mata, J. (2005). Counterfactual decomposition of changes in wage distributions using quantile regression. Journal of Applied Econometrics, 20, 445-465. 
Madheswaran, S., \& Attewell, P. (2007). Caste discrimination in the Indian urban labour market: Evidence from the national sample survey. Economic and Political Weekly, 4146-4153.

Melly, B. (2006). Estimation of counterfactual distributions using quantile regression. Review of Labor Economics, 68, 543-572.

Melly, B. (2007). RQDECO: A stata module to decompose differences in distribution. Unpublished manuscript, University of St. Gallen.

Nordman, C. J., Sarr, L., \& Sharma, S. (2015). Cognitive, noncognitive skills and gender wage gaps: Evidence from linked employer-employee data in Bangladesh, IZA Discussion Paper No. 9132.

Oaxaca, R. (1973). Male-female wage differentials in urban labor markets. International Economic Review, 14, 693-709.
Oaxaca, R., \& Ransom, M. (1994). On discrimination and the decomposition of wage differentials. Journal of Econometrics, 61(1), 5-21.

Pham, T., \& Reilly, B. (2007). The gender pay gap in Vietnam: 1993-2002: A quantile regression approach. Journal of Asian Economics, 18(5), 775-808.

Prakash, A. (2010). Dalit entrepreneurs in middle India. In Barbara Harriss-White \& Judith Heyer (Eds.), The comparative political economy of development Africa and South Asia. London: Routledge.

Thorat, S., \& Newman, K. (Eds.). (2010). Blocked by caste: Economic discrimination in modern India. New Delhi: Oxford University Press.

Thorat, S., \& Sadana, N. (2009). Caste and ownership of private enterprises. Economic and Political Weekly, XLIV(23), 13-16. 